Vishva Bandhu Śāstrī

1942-1976 Vaidika-Padānukram-Koșah. A Vedic Word-Concordance. Lahore/Hoshiarpur: Vishveshvaranand Vedic Research Institute.

Wackernagel, Jacob and Albert Debrunner

1896-1930 Altindische Grammatik. 3 vols. (I 1896, ${ }^{2} 1957$; II,1 1905, ${ }^{2} 1957$; II,2 1954; III 1930, Register 1964). Göttingen: Vandenhoeck \& Ruprecht.

Wennerberg, Claes

1981 Die altindischen Nominalsuffixe -man- und -iman- in historisch-komparativer Beleuchtung. I. Wortanalytischer Teil - Wörterbuch -. Gothenburg: Göteborgs Universitet. [2.4.8]

Whitney, William Dwight

1889 A Sanskrit Grammar. $2^{\text {nd }}$ edn. Cambridge, MA: Harvard University Press.

Toshifumi Gotō, Morioka and Tōkyō (Japan)

\title{
28. The syntax of Indic
}

1. Word classes

2. Nominal morphosyntax

3. Verbal morphosyntax

4. Non-inflectional words
5. Word order

6. Sentence syntax and complex sentences

7. Abbreviations

8. References

\section{Word classes}

The inventory of word classes (parts of speech) which are relevant for a syntactic description of Indic, as in most other ancient Indo-European languages, consists of: verb, substantive, adjective (with pronominal adjectives), adverbials, and a few minor categories of non-inflexional lexemes, the most important of which includes particles.

\section{Nominal morphosyntax}

\subsection{Grammatical relations and cases}

\subsubsection{Grammatical relations and types of alignment}

The main grammatical relations which are relevant for a description of Old Indo-Aryan nominal syntax include Subject (S), Direct Object (DO), Indirect Object (IO), and a variety of Oblique Objects (Obl). In its earliest forms (Vedic), Old Indo-Aryan follows the nominative-accusative pattern of alignment, with $\mathrm{S}$ in the nominative and DO either in the accusative (canonical marking), or in some oblique cases: locative, genitive, or instrumental (non- 
canonical marking). The subject is, by contrast, almost uniformly encoded with the nominative, with only rare exceptions (see, in particular, Hock 1990); on some alleged instances of oblique subjects, see Verbeke, Kulikov and Willems 2015: 24-27.

For the ergative analysis of constructions with verbal adjectives ("perfect passive participles") in -tá-/-ná- and the passive agent in the genitive (Andersen 1986), see 3.3.1.3.1 below.

From late Old Indo-Aryan and, especially, from Middle Indo-Aryan onwards, when the instrumental argument of -tá-/-ná-adjectives ("participles") acquires some subject properties (see, in particular, 6.1.2), these constructions give rise to the ergative syntactic pattern.

\subsubsection{Cases and their main uses}

The main uses of the Old Indo-Aryan cases are typical for ancient Indo-European languages.

The nominative is employed as the case of subject as well as in the predicative function.

The vocative is attested, alongside its main use (vocative proper), in rare non-vocative (predicative) uses, as in the textbook example (see Delbrück 1888: 106) RV 6.31.1a ábhūr éko rayipate rayịnăm 'You alone have become the Lord of wealth' (lit. 'you ... have become - o Lord of wealth!'). The similar construction with the nominative rayipátī in $\mathrm{RV} 2.9 .4 \mathrm{c}$ tvám $h_{i}$ y ási rayipátī rayīnắm '... because you are the Lord of wealth' shows that the vocative in such instances is secondary. In coordinating structures built with the conjunction $c a$, the second vocative is replaced by a nominative: RV 1.2.5 váa yav indraś ca 'O Vāyu and Indra!'.

The main function of the accusative is the encoding of the direct object (DO). Next to this type, there exists a variety of other usages, including accusative of goal, accusative of time, content accusative, and some others (see Gaedicke 1880; Gotō 2002). The main criterion of the objecthood of a noun phrase, distinguishing the accusative of DO from other usages, is the passivization test (= the ability of a verb to passivize, that is, to form passive constructions with -yá-presents or other morphological passives) (cf., e.g., Delbrück 1988: 104 f.; Haudry 1977: 149; Kulikov 2012b). In spite of its obvious shortcomings (see Jamison 1979b: 197 ff., 1983: $30 \mathrm{ff}$.), it can be quite successfully used for distinguishing various types of accusative arguments according to their objecthood. Usually, constructions with canonical DOs (= prototypical transitives) can readily be passivized, while constructions with accusatives of other types can only be passivized rarely, exceptionally, or never (see Gaedicke 1880; Delbrück 1888: 164 ff.; Gonda 1957a, 1957b; Jamison 1983: 27 ff.; for Classical Sanskrit, see Ostler 1979: 242 ff.; Hock 1982: 131).

On the basis of $-y a$-passivization, the variety of usages of the accusative can be qualified as ranking between the canonical DO and clear instances of non-DO accusatives. In particular, it can be demonstrated that accusatives of time (as in RV 10.161.4a śatám jīva śarádo várdhamānah 'Live hundred autumns in prosperity'; see Gaedicke 1880: 175 ff.; Gonda 1957a: 54 ff. [= 1975: $51 \mathrm{ff}$.$] , 1957b: 75$ f. [= 1975: $66 \mathrm{f}$.$] ) and$ accusatives of goal (as in RV 1.110.2 ágachata savitúr [...] grhám 'You went to the 
house of Savitar'; RV 9.56.2a yát sómo vájjam árșati 'when Soma runs to the prize ...'; see Gaedicke 1880: 125 ff., 144 ff.; Wecker 1906: 4 ff.; Gonda 1957a: 52 ff. [= 1975: 49 ff.]; "facientiv mit affiziertem Objekt" in Gotō [1987] 1996) never promote to passive subjects and thus show the lowest degree of objecthood.

There are virtually no examples of passive counterparts of constructions with the content accusative, commonly derived from the same root as the governing verb (other, partly synonymous, terms include: Inhaltsakkusativ; accusative of relation/scope/parameter; "cognate object", figura etymologica, etymologischer Akkusativ), which denote, generally, the scope of application of the given (intransitive) activity and/or its result. Cf. RV 9.49.3 ghrtám pavasva 'purify yourself [into] ghee'; RV 2.2.6 rayím asmấsu dīdihi (lit.) 'shine wealth for us'; RV 9.97.50a abhi vástrā suvasanán $n_{i}$ arșa 'flow (for) wellfitting (lit. well-clothing) clothes'; RV 7.56 .5 sá̀ vít ... púsyantī nrmṇám 'this tribe, ... prospering in manliness'). On this type, see Gaedicke (1880: $88 \mathrm{ff}$.); Delbrück (1888: $175 \mathrm{f}$.); Oertel (1926: $31 \mathrm{ff}$. [with a rich collection of examples and detailed discussion]); Haudry (1977: 195 ff.); Jamison (1983: 29, fn. 9); Kulikov (1999a: 236 ff.). For constructions with the content accusative (= Inhaltsakkusativ), typically derived from the same root as the governing verb (e.g. in RV 6.2.1 puștím ... puṣyasi (lit.) 'you prosper prosperity'; AV 11.3.56 ná ca sarvajyanním jūyáte 'if he is not deprived of the whole property ...'; on this type, see Gaedicke 1880: $156 \mathrm{ff}$.; Sen 1927: $360 \mathrm{ff}$.; Jamison 1983: 29, with fn. 9; Kulikov 1999a), we only find two examples of passivization in Vedic: TS 1.7.6.2 viṣnukramáh kramyánte 'the strides of Viṣnu are stridden' and nrtyate JB '[the dance] is danced'.

For the syntactic status of accusative nouns in constructions with intransitive verbs with preverbs, see 3.1.3 below.

Two standard functions of the genitive are: (i) the case of the possessor, and (ii) the case of S and DO with deverbal nouns (subjective and objective genitive with nominalizations). Besides, the genitive is used for non-canonical DO marking (usually, with a partitive meaning; see 3.1.2) and, alongside with the instrumental, for the encoding of the passive agent (see 3.3.1.3.1).

The dative is the case of the IO, which typically expresses the beneficiary of an event, but also, in many constructions, corresponds to the goal or second (remote) object of the activity (see 3.1.5).

The uses of the three other oblique cases, instrumental (tool; passive agent; concomitance, etc.), ablative (see Hettrich 1995) and locative, do not require special discussion.

Comprehensive surveys of the main uses of cases can be found in Delbrück (1888: 103 ff.); Speijer (1886: 26-113, 1896: 6 ff.); Oertel (1926); Sen (1927); Gotō (2002); Hettrich (2007). For syntactic patterns (case frames) attested with individual verbs, see especially s.vv. (individual verbal entries) in Grassmann 1873 (out-of-date at many points, but still very useful), Hettrich 2007, Krisch 2006; 2012 (on-going edition).

\subsubsection{Cases with adpositions}

Adpositions (most often, postpositions; see 4.1) select the case form of the noun of the adpositional phrase, which is, most commonly, the accusative. Usually, the adpositions are constructed with the following cases (only the most frequent combinations are listed): 
- with the accusative: áti, ádhi, ánu, antár ('between'), abhi, áa, úpa, práti;

- with the ablative: ádhi, $\frac{a}{a}$ ('hither from'), pári;

- with the locative: ádhi, antár ('within'), $\bar{a}$ ('among').

On ádhi (which can be constructed with nearly all oblique cases and, on the basis of some syntactic features, should be qualified as an adverb(ial), rather than an adposition), antár and pári, see Hettrich (1991, 1993, 2002).

\subsection{The syntax of adjectives: agreement}

Adjectives (including pronominal adjectives and participles) agree with the substantive in gender, case, and number.

\subsection{The syntax of pronouns}

\subsubsection{Personal pronouns}

As in other ancient Indo-European languages, such as Latin or Greek, personal pronouns (for their morphological survey, see Gotō this handbook: 4.1) are frequently omitted when in the subject position (PRO-drop language).

\subsubsection{Demonstrative pronouns}

For a morphological survey and semantic summary of demonstrative pronouns, see Gotō (this handbook: 4.2), Kupfer (2002), and Knobl (forthcoming) (for the language of the RV); Gotō (2013: 67 ff.); Dunkel (2014 s.vv.). The demonstrative pronouns can be employed in deictic (eșá-/etá- and accented forms of $a$-/i- [ayám/iyám/idám] - proximal deixis; amú- [asáu/adás] - distal deixis; syá-/tyá- - deixis, in particular, first-person or non-third person reference, see Klein 1998) and/or anaphoric (sá-/tá-; eșá-/etá-; syá-/tyá-; enclitic forms of $a-/ i-$; encl. ena-; encl. ìm) usages; the demonstrative pronoun sá-/tácan also be used as $3^{\text {rd }}$ person pronoun ('he/she/it/they'). In addition, they attest a few "minor" types of usages, such as cataphoric (possible for many of the pronouns employed in anaphoric usages, in particular, for $t a ́-/ s a ́-)$ or emphatic (e.g. for encl. $\bar{\imath} m$ ).

Next to substantive (independent) and adjectival usages possible for the majority of these pronouns, some forms of the paradigm can also be employed in fossilized adverbial usages, as is the case with idám (nom.-acc.sg.n. of $a-/ i$-) 'here, to this place; now', tád (nom.-acc.sg.n. of tá-) 'then, at that time; thus' or tyád (nom.-acc.sg.n. of tyá-) 'here, indeed'.

A peculiar usage is attested for the pronoun $t a ́-/ s a ́-$, which is employed in sentenceinitial position in the function of an extraclausal connective particle (traditionally called "sa-figé"), as in TS 7.3.1.1 sá yó vái daśamé 'hann avivākyá upahanyáte, sá hīyate 'Now, the one who makes a recitation mistake on the tenth day, the Avivākya, falls behind'; see Jamison (1992); Klein (1996); Hock (1997); Kupfer (2002: 189 ff.). Further- 
Tab. 28.1: Morphosyntactic types of compounds

\begin{tabular}{|c|c|c|c|c|c|}
\hline & \multicolumn{4}{|c|}{ equivalent to $\mathrm{N}_{2}$} \\
\hline & & \multicolumn{2}{|c|}{+} & \multicolumn{2}{|l|}{-} \\
\hline \multirow{5}{*}{$\begin{array}{l}\text { equivalent } \\
\text { to } N_{1}\end{array}$} & + & 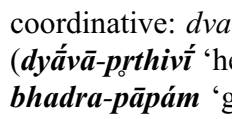 & $\begin{array}{l}\text { d earth' } \\
\text { evil') }\end{array}$ & $\begin{array}{l}\text { governing compounds } \\
\text { (dhārayát-kavi- } \\
\text { 'supporting the wise') }\end{array}$ & \\
\hline & \multirow{4}{*}{-} & $\begin{array}{l}\text { determinative: } \text { tat } \\
\text { (havir-ád- 'oblati } \\
\text { rāja-putrá- 'king }\end{array}$ & & $\begin{array}{l}\text { tatpuruṣa-based } \\
\text { (sútrya-tejas- 'having the } \\
\text { radiance of the sun') }\end{array}$ & \multirow{4}{*}{$\begin{array}{l}\text { (posses- } \\
\text { sive:) } \\
\text { bahu- } \\
\text { vrīhi }\end{array}$} \\
\hline & & $\begin{array}{l}\text { numeral: dvigu } \\
\text { (sapta-rșí- 'seven }\end{array}$ & & $\begin{array}{l}\text { dvigu-based } \\
\text { (saptá-raśmi- } \\
\text { 'having seven ropes') }\end{array}$ & \\
\hline & & $\begin{array}{l}\text { attributive } \\
\text { (mahā-vīrá- } \\
\text { 'great hero'): }\end{array}$ & \multirow{2}{*}{$\begin{array}{l}\text { descrip- } \\
\text { tive: } \\
\text { karma- } \\
\text { dhāraya }\end{array}$} & $\begin{array}{l}\text { attr. karmadhāraya- } \\
\text { based (ugrá-bāhu- } \\
\text { 'having powerful arms') }\end{array}$ & \\
\hline & & $\begin{array}{l}\text { appositional } \\
\text { (purușa-mrgá- } \\
\text { 'male antelope'): }\end{array}$ & & $\begin{array}{l}\text { app. karmadhāraya- } \\
\text { based (indra-śatru- } \\
\text { 'having Indra as a foe') }\end{array}$ & \\
\hline
\end{tabular}

more, $t a ́$-/sá- may be attributively connected with the $2^{\text {nd }}$ person pronoun $(t v \bar{a})$, as in RV 8.51.6 yásmai túvám vaso dānắya śíkșasi / sá rāyás póṣam aśnute / tám tvā vayám [...] havāmahe 'The one whom you wish to help for giving, $\mathrm{O}$ good one, reaches prosperity in wealth. We call you as such one ...'

Adverbial usages of pronouns must also underlie a number of adverbs and particles which historically go back to fossilized forms of the pronominal paradigm (later replaced by innovations), such as $i d$ 'only' ( $\leftarrow^{*}$ nom.-acc.sg.n. of $i$-), tấd ( $\leftarrow *$ abl.sg. of $\left.t a-\right)$ 'thus, in this way' ( $2 \times$ in the RV) or aná 'hereby, thus, indeed' ( $\leftarrow$ *inst.sg. of $a$-).

\subsection{The morphosyntax of compounds}

The main morphosyntactic types of compounds can be captured in terms of their properties in the form of a simple calculus based on the following two parameters:

(i) Is the compound (schematically represented as $\mathrm{N}_{1}-\mathrm{N}_{2}$, where $\mathrm{N}_{1}$ and $\mathrm{N}_{2}$ stand for the first and second members of the compound) syntactically equivalent to or substitutable for $\mathrm{N}_{1}$ ?

(ii) Is the compound $\left(\mathrm{N}_{1}-\mathrm{N}_{2}\right)$ syntactically equivalent to or substitutable for $\mathrm{N}_{2}$ ?

Positive answers to at least one of these questions roughly correspond to the endocentric type (that is, the syntactic centre of the compound lies within it); in case of negative answers to both (i) and (ii), we are confronted with the exocentric, or bahuvrihi, type. This calculus of logically possible morphosyntactic types of compounds is summarized in table 28.1; the syntactic centres of the compounds are in boldface. 


\section{Verbal morphosyntax}

\subsection{The main syntactic classes of verbs}

\subsubsection{Intransitive and transitive}

The canonical intransitive and transitive patterns do not require special discussion. Many transitive verbs can also be employed without direct objects, i.e. in absolute usages particularly, in the cases of a non-referential direct object, as in RV 1.147.2c pityati tvo ánu $t_{u}$ vo grṇäti 'One [sacrificer] blames [my speech], another praises'. The common term for this pattern (see Jamison 1983: 27) is "absolute transitive", or "objectless transitive". The absolute transitive usages are common for verbs describing various occupation-related activities (sing, write, etc.).

A particular semantic subtype of the transitive pattern, common with middle forms, as opposed to non-marked active forms, is often referred to as "transitive-affective" (see Gotō 1996: 27 f.), or transitive with the self-beneficent sense; see 3.2.2. The affective (self-beneficent) meaning has no impact on the syntactic pattern. For a special subclass of transitive-affective usages, where the direct object refers to a property or body part of the agent (as in TS 6.1.1.5 dákșinam púrvam ấnkte 'he anoints his right [eye] first'), I will use the term "possessive-reflexive".

\subsubsection{Intransitive/transitive}

The term "intransitive/transitive" (I/T), introduced by Jamison (1983: $31 \mathrm{ff}$.), refers to verbs which can be constructed either with the accusative direct object or with some oblique objects (locative, genitive, etc. = "differential object marking"), as in the case of the verb $p \bar{a}$ 'drink', cf. RV 8.36.1 píba sómam 'drink Soma' RV 8.37.1 píba sómasya 'drink (of/some) Soma' (see Dahl 2009). This class includes, above all, verbs of perception ('śru 'to hear', vid 'to know'), enjoying (juṣ 'to enjoy') and consuming/ ingestion ( $p \bar{a}$ 'to drink', bhaj 'to share in').

\subsubsection{Intransitive compounds constructed with accusatives}

It is a commonplace in Sanskrit scholarship that intransitive verbs typically become transitive after certain spatial (directional and locational) preverbs, such as ánu 'along, after', áti 'over', abhi 'towards, over, against', úpa 'to, near' and some others, which add an accusative object to the syntactic arguments of the verb and thus function as transitivizing, or applicative, markers, as in RV 9.19.3 (quoted in 4.1.2), RV 7.1.14a séd agnír agním $\dot{m} r \boldsymbol{a}_{i} \boldsymbol{y} \boldsymbol{a s t}_{\boldsymbol{u}} \boldsymbol{v}$ anyắn 'Let this fire be bigger than (lit. be over) other fires'; or ŚB 1.7.2.12 vŕṣa á yóṣam ádhi dravati 'The bull covers (impregnates) the female cow.' Cf., e.g., Gaedicke (1880: 91): "Jedes Intransitivum wird im Indischen durch gewisse Richtungswörter oder Präpositionen zu einem Transitivum [In Indic, any intransitive may become a transitive through certain direction words or prepositions]"; see also Speijer (1886: 32, 1896: 7); Sen (1927: 368 ff. [= 1995: 28 ff.]); Renou (1952: $316 \mathrm{ff}$.). For a 
rich collection of examples, see Gaedicke (1880: $91 \mathrm{ff}$.); Sen (1927: $368 \mathrm{ff}$.); cf. also Gonda (1957a: $61 \mathrm{ff}$. [= 1975: $58 \mathrm{ff}.], 1957 \mathrm{~b}: 78 \mathrm{f}$. [= 1975: $69 \mathrm{f}]$.$) ; Ostler (1979: 344 \mathrm{f}$.).

The exact syntactic status (transitivity) of such verbs poses several problems, however. Should compounded verbs such as $\stackrel{a}{a}-s a d$, áti-as, or ádhi-dru be considered as intransitives constructed with accusatives (which are not, however, true direct objects), rather than as true transitives? This can be demonstrated (see Kulikov 2012b for details), foremost, by using the -yá-passivization test, which neatly distinguishes transitives from other syntactic classes of verbs in Vedic. Only a few fundamentally intransitive verbs form $-y a$-passives in compounds (i.e. when employed with preverbs) in Vedic. These include, in particular, úpa + iyate ( $\leftarrow i$ 'go') 'sexually approach, copulate' YV+; ádhigamyáte ( $\leftarrow$ gam 'go') 'find, know, understand' AV+; adhi-șthiyate ( $\leftarrow$ sthā 'stand') 'stand upon' KS 13.3: 182.1. Importantly, virtually all such passivizable compounds show some idiomatic semantic changes, i.e. the meaning of the resulting verb cannot be deduced from that of the non-prefixed verb (simplex) and preverb; cf. ádhi-ștha 'govern' ( $\neq$ 'stand' + 'over'); úpa-i 'sexually approach, impregnate' ( $\neq$ 'go' + 'to, near'), etc.

\subsection{4. "Two pattern" verbs and double object constructions}

This subclass comprises verbs which can be constructed with two kinds of accusative objects; they can be referred to as first [proximate] and second [distant] objects. The second object ("recipient" or locative direct object) typically denotes the goal or addressee (pradhāna-karman 'principal object' and apradhāna-karman 'non-principal, secondary object' in Indian tradition; see Deshpande 1991: $21 \mathrm{ff}$.) - as, e.g., is the case of $y u j$ 'yoke, join', constructed with the accusative of horses (as in RV 8.98.9 yuñjánti hárī... ráthe 'they yoke two fallow [horses] to the chariot') or with the accusative of 'chariot' (as in RV 7.23.3 yujé rátham ... háribhyām 'in order to yoke the chariot ... with two fallow [horses] ...'). Usually, only one of these two participants surfaces in the accusative; the first object can alternatively appear in the instrumental and the second object in the dative or locative. Constructions with two accusative objects are also possible with some verbs (see Gaedicke 1880: 255 ff.; Hock 1985; Hettrich 1994), cf. RV 8.27.1 rcáa yāmi marúto bráhmanas pátim / devấm̆ ávo váren ${ }_{i} y a m$ 'With a hymn I approach the Maruts, Brhaspati, the gods for the desirable help'. On this syntactic phenomenon, see Delbrück (1897: 438 f.); Haudry (1977: Chapter 3, esp. p. 175 ff.); Jamison (1979a: 135, fn. 11); Hock (1982: 135, note 5). The passivization test enables one to determine whether both types of accusative nominals behave as DOs or not and thus to distinguish "two pattern" verbs (also labelled "ditransitives") from other verbs with multiple accusatives; see Kulikov 2012a: $701 \mathrm{ff}$. On the passivization of ditransitives, see Deshpande (1991).

The two main semantic groups of "two pattern" verbs in Vedic include verbs of speech (with the accusative of speech or with the accusative of the addressee of the speech [= second object]: ' $\mathrm{X}_{\mathrm{NOM}}$ sings $\mathrm{Y}^{\text {prayer }}{ }_{\mathrm{ACC}}$ ' or ' $\mathrm{X}_{\mathrm{NOM}}$ praises $\mathrm{Z}^{\text {deity }}{ }_{\mathrm{ACC}}$ ') and verbs of putting/spraying (with the accusative of movable things or substances or with the accusative of the goal; this type of syntactic alternation is also known as "locative alternation"): ' $\mathrm{X}_{\mathrm{NOM}}$ sprinkles $\mathrm{Y}^{\text {oblation }}{ }_{\mathrm{ACC}}$ ' or ' $\mathrm{X}_{\mathrm{NOM}}$ besprinkles $\mathrm{Z}^{\mathrm{altar}}{ }_{\mathrm{ACC}}$ '. 


\subsection{The main verbal morphosyntactic categories}

\subsubsection{Verbal agreement}

Finite verbal forms agree with the subject in person and number. Cases where the verb agrees with only one of the group of coordinated subjects (thus taking the singular form) are possible, as in RV 7.40.2ab mitrás tán no váruṇo ródasī ca ' dyúbhaktam índro aryamá dadātu 'Let Mitra, Varuṇa, Rodasī, Indra and Aryaman give us the heavenly wealth'.

For the peculiarities of verbal agreement in constructions with the reciprocal pronoun anyó (a)nyám, see 3.3.5.3.2.

\subsubsection{Diathesis}

The category of diathesis is formed by the opposition of forms with the active vs. middle inflexion. The range of the functions rendered by the middle type of inflexion (= middle diathesis) is typical of the ancient Indo-European linguistic type as attested in "Classical" languages (Ancient Greek, Latin). Here belong the self-beneficent (auto-benefactive) meaning with no valence change ('to do smth. for oneself', as in the handbook example yájati 'sacrifices' yájate 'sacrifices for oneself') as well as a number of intransitivizing derivations, such as passive, reflexive, and anticausative (decausative). The choice of the function(s) idiosyncratically depends on the base verb. However, already in the language of the earliest text, the RV, we observe the loss of several grammatical functions of the ancient Indo-European middle, and the intransitivizing functions are largely taken over by special productive markers, such as the passive suffix $-y a$ - and the reflexive pronouns tanú- and ātmán- (this process can be regarded as degrammaticalization of the middle, see Kulikov 2012c). By contrast, the auto-benefactive meaning proves to be more stable and becomes the main function of the middle diathesis.

The auto-benefactive functional domain of the middle diathesis includes (see Kulikov 2012c: $172 \mathrm{ff}$.): (i) the self-beneficent meaning proper ("subjective version"), i.e. 'to do smth. for oneself', the handbook example is yájate 'he performs sacrifice for himself'; (ii) possessive-reflexive (the subject is referentially identical with the possessor of another argument, cf. TS 6.1.1.2 nakhăni ni krntate 'he cuts off his nails'; ŚB 1.2.5.23 átha pāṇ̂́ áva nenikte 'then he washes his hands'); and (iii) auto-directional, which includes transitive verbs of caused motion, typically referring to the motion of the referent of the DO caused by the Agent. Their middle counterparts, most often used with preverbs such as $\frac{a}{a}$ 'to(wards)', denote the process of the motion of the object towards the Agent, such as obtaining or taking of the object by the Agent. The handbook example of this type is the conversive pair $d \bar{a}$ (active) 'give' $\sim \bar{a}-d \bar{a}$ (middle) 'take'; cf. also as (active) 'throw'

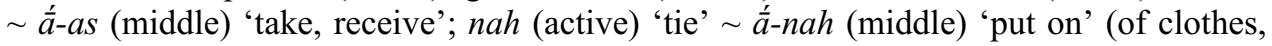
protection, etc.).

3.2.3. The main uses of tenses and moods are summarized in Gotō (this handbook: 5.35.7). For the most recent clear and comprehensive survey of the uses of moods in Vedic prose, see also Tichy (2006: $67 \mathrm{ff}$.); for injunctive, see Hoffmann (1967).

On correlations between tense and transitivity oppositions, see 3.3.2.1 below. 


\subsection{Voice and valency-changing categories}

\subsubsection{Passive}

\subsubsection{Passive formations}

There are several verbal formations in Vedic which can be employed in passive constructions. Non-finite passives include verbal adjectives (called in many grammars "perfect passive participles") with the suffix -tá-/-ná- (on the ergative reanalysis of constructions with these participles in late Sanskrit, see 2.1.1 and 3.3.1.3.1); gerundives, or future passive participles, with the suffixes -ya-, -tavyà- and -antya-; and, less regularly, some other non-finite formations, such as infinitives in -tavái (-tave), as in RV $7.33 .8 \mathrm{~cd}$ vắtasyeva prajavó nắn ${ }_{i}$ yéna ' stómo vasișthā án ${ }_{u}$ vetave vaḥ 'O Vasișṭas, your praise is not to be caught up by another, like the flight of the wind'.

Finite passive formations include the following (for details, see Kümmel 1996; Gotō 1997; Kulikov 2006):

(i) In the present system: presents with the suffix - yá- (derived from the root by means of the suffix $-y(\dot{a})$-, which can only take middle endings; e.g. han 'to kill': 1sg. han-yé, 2sg. han-yá-se, 3sg. han-yá-te, etc.). In early Vedic, only the $3^{\text {rd }}$ person singular and plural forms as well as participles are well-attested. Next to a dozen 2sg. forms (yujyáse 'you are (being) yoked', śasyáse 'you are (being) praised', etc.), we only find one occurrence of a $3 \mathrm{du}$. form, ucyete (RV 10.90.11) '[the two feet] are called' and one (philologically and grammatically rather unclear) form -panyámahe, which may represent 1pl. ('we are [being] glorified'[?]; see Kulikov 2012a: $144 \mathrm{ff}$.). $1 \mathrm{sg}$., 1du., 2du. and 2pl. forms are unattested. Next to present forms proper, participles and rare imperatives (10 forms or so in the RV and AV), only exceptional attestations of other tense-moods are found (3sg.impf. aniyata '(she) was brought' in RV 8.56.4 = Vālakh. 8.4 and 3pl.impf. -ásicyanta '(they) were besprinkled' in AV 14.1.36; 3sg.inj. süyata '(he) is consecrated' in RV 10.132.4; and 3sg.subj. -bhriyāte RV 5.31 .12 '(it) will be brought').

(ii) In the aorist system: medio-passive $i$-aorists (with a defective paradigm: only $3 \mathrm{sg}$. in $-i$, and, in the RV, 3pl. in -ran/-ram and participle; e.g. yuj 'yoke, join': 3sg. áyoji, 3pl. áyujran, part. yujāná-);

(iii) In the perfect system: statives can be used in the function of passive perfects for some verbal roots, an employment almost exclusive to early Vedic. An example (with a defective paradigm: $3 \mathrm{sg}$. in $-e, 3 \mathrm{pl}$. in -re and participle) is $h i$ 'impel': $3 \mathrm{sg}$. hinvé '(it) is impelled', 3pl. hinviré '(they) are impelled'; part. hinvāná-. Indeed, there are reasons to consider statives as part of a larger, perfect-stative system. Forms built on perfect stems with middle endings and employed in passive constructions (almost exclusively 3sg. and 3pl.; e.g. dha 'put': 3sg. dadhe 'is put/has been put'; yuj 'yoke': 3pl. yuyujré 'are yoked/have been yoked') should be regarded, accordingly, as statives built on perfect stems.

(iv) Besides the above, there are a few isolated and rare non-characterized (bare) middle forms, such as class I pres. stávate 'is praised', class IX pres. grnitté 'is praised'; class III (reduplicated) pres. mímite 'is measured' (RV 8.2.10); and a few sigmatic 
aorists (mostly 3pl. forms): ayukșata '(they) were yoked', adrkșata '(they) were seen, visible, (they) appeared', asrkșata '(they) were set free'. stávate is the only formation in this group which quite commonly occurs in passive constructions in the RV; both stávate and grnité are likely to be based on the statives stáv-e (see Narten 1968) and grn-é 'is praised', instantiating back derivation (Rückbildungen).

\subsubsection{Constraints on passive derivation}

The growth of productivity of the $-y a$-passives is well-documented in texts (see Kulikov 2012a: $751 \mathrm{ff}$.). While in the language of the RV -yá-passives are attested only for about 40 roots, the younger mantras (Atharvaveda and Yajurveda) double this number. In early Vedic (RV and AV), only non-derived transitive verbs can be passivized. The middle Vedic texts not only attest numerical growth of the -yá-passives, but also the first examples of -yá-passives derived from secondary stems, such as causatives and desideratives. The earliest attestations of causative passives appear in the young Yajurvedic mantras: $\bar{a}$-pyāyyámāna 'being made to swell' (root pyā 'swell') VS +, pra-vartyámāna- 'being rolled forward' ( $v_{0} r$ 'turn') $\mathrm{MS}^{\mathrm{m}}$, sādyáte 'is (being) seated, set' (sad 'sit') YV ${ }^{\mathrm{m}}+$. Other formations of this type are attested from Vedic prose onwards and become more common in the Brāhmaṇas.

Until the very end of the Vedic period only causatives built to intransitives can passivize. Passives of causatives derived from transitives or intransitive/transitive verbs first appear in late Vedic / post-Vedic texts, from the Śrautasūtras onwards. The earliest examples are: VaitS 5.17 aśvapādam lakṣaṇe nidhāpyamānam sam adhvarāyety anu mantrayate 'Along with ( $a n u)$ the horse's foot which is being caused to be put down on the (demarcation) line [of the āhavanīya-fire] he (sc. the adhvaryu-priest) pronounces the mantra sam adhvarāya ... "To the sacrifice ..." (AV 3.16.6)'; ĀpŚS 9.18.11 yady upapāyyamāno na piben na vā uv etan mriyasa iti upa pāyayet 'If [the sacrificial animal], though being [respectfully?] caused to drink, does not drink, he (sc. the adhvaryupriest) should cause it to drink [by pronouncing the mantra]: na vā uv etan mriyase "Verily, you do not die here ..." (TS ${ }^{\mathrm{m}}$ 4.6.9.4 RV 1.162.21 etc.)'; VādhS 4.101:9 sa yo ha vā evamvidādhvaryunā yājyamāno yajamāno na rdhnoti 'If the institutor of the sacrifice (yajamāna), though being caused by the thus-knowing adhvaryu to perform a sacrifice, does not succeed ...'; vācyamāna- in VaikhŚS 18.5:256.6 and KauśS 63.20 dadyād dātā vācyamānah '... the giver who is made to pronounce (the ritual words) should give (the oblation)'; see Kulikov (2008: 250).

\subsubsection{Syntax of passive constructions}

\subsection{Case marking of the passive agent}

Passivization typically suggests (i) the promotion of the initial direct object to the subject position (= the subject of the passive construction or passive subject for short) and (ii) the demotion of the initial subject (usually, an agent). The demoted subject either be- 
comes an oblique object (encoded by the instrumental case, as, e.g., in RV 9.86.12d $s_{u} v \bar{a} y u d h a ́ h$ sotŕbhih pūyate vr'șā '[Soma], the well-armed bull, is being purified by pressers'; more rarely by the genitive case (cf. RV $1.61 .15 \mathrm{a}$ asmá̀ id u tyád ánu dāy $y_{i} y$ eșām 'This very thing has been granted to him by them') or, more frequently, remains unexpressed (see Gonda 1951: 77 f.), as in RV 9.97.35c sómaḥ sutáh pūyate ajyámānah 'Soma, pressed out, is purified, being anointed.' See Jamison (1979a: 133 ff.); Andersen (1986). On the case of the agent in Vedic, see Wenzel (1879: $102 \mathrm{ff}$.); Jamison (1979a); Hettrich (1990). Agentless passive constructions can be illustrated by such examples as RV 10.97.6c víprah sá ucyate bhișák 'This poet is called healer ...; RV 10.22.1ab kúha śrutá ind ${ }_{a}$ rah kásminn adyá ' jáne mitró ná śrūyate 'Where has one heard about Indra? In which community is he known today as a friend?'. On the ratio of agentive passives and passives without agent, see Jamison (1979b: $202 \mathrm{ff}$.).

There are some reasons to treat Vedic constructions with verbal adjectives ("perfect passive participles") in -tá-/-ná- and the genitive marking of the agent separately from canonical passives with the instrumental. According to Andersen (1986), the genitive noun displays a number of subject properties (usually animate; definite and/or refers to old information) in such constructions, and therefore they should be qualified as ergative rather than passive properly speaking.

\subsection{Passives derived from causatives}

With three of the four attested passives derived from causatives (see 3.3.1.2), the causee (= the subject of the embedded causative construction) becomes passive subject (cf. Hock 1981: $22 \mathrm{f}$.). This is the case with upa-pāyyamāna-, yājyamāna-, and vācyamāna-. Only in the case of ni-dhäpyamana- 'being caused to be put down', the passive subject corresponds to the initial object. This tendency parallels what is seen in Epic and Classical Skt., where both causee and initial object can become passive subject, but the latter pattern is less common (see Hock 1981: 24 ff.; Bubenik 1987).

\subsubsection{Causative}

\subsubsection{The system of causative oppositions}

The most regular and productive causative marker in the present system is the suffix -(p)áya-, cf. vrdh 'grow, increase' - vardháyati 'makes grow, increases', cit 'appear, perceive' - cetáyati 'shows (= makes appear), makes perceive' ( citáyati 'appears'). In addition to - $(p)$ áya-causatives, in early Vedic we find a few other (non-productive) formal types of present causative oppositions. In particular, the transitive-causative member is not infrequently expressed by a present with the nasal affix, that is, suffixes $-n o$-/-nu(class V), $-n \dot{a}-/-n \bar{l}$ - (class IX) or nasal infix -ná-/-n- (class VII), often opposed to an intransitive (anticausative) present with the suffix $-y a$ - (class IV) or a root present with thematic vowel (class I). Causative oppositions of other types (for instance, with the causative member expressed by a reduplicated present, or by a class VI present, as in the pair tárati/-te 'passes, crosses over' $\sim$ tirátil-te 'carries through, saves'; see Gotō 
1996: $160 \mathrm{ff}$.) are less common (see e.g. Joachim 1978: $21 \mathrm{ff}$.). There are also a few examples of anticausatives expressed by middle presents with the suffix $-y a$ - and "passive" accentuation (accent on the suffix). This passive-to-anticausative transfer is attested, foremost, for passives of several verbs of perception and knowledge (knowledge transfer) such as drśyáte ' $\mathrm{X}$ is seen' $\rightarrow$ ' $\mathrm{X}$ is visible; appears', śrūyáte 'is heard, is known, is famous' - obviously, according to the scenario ' $\mathrm{Y}$ is seen (known, etc.) by smb.' $\rightarrow$ 'Y is seen (known, etc.) [by smb.]' $\rightarrow$ 'Y is seen (known, etc.) [by generic passive agent]' $\rightarrow$ 'Y is visible (famous, etc.)'. A special variety of this development is instantiated by the passive of a verb of speech, ucyáte ' $\mathrm{Y}$ is pronounced' $\rightarrow$ 'Y [e.g. speech, musical instrument] sounds'. Besides, such semantic development is attested for a small subgroup of verbs of caused motion, such as -kīryáte 'is scattered; falls (down)' or sicyáte 'is poured; pours (out)'. While in this latter case the rise of anticausative usages may be due to conceptualizing simple transitives as causatives (scatter = 'make fall, make fly', etc.), in cases of verbs of perception and knowledge we observe the rise of the anticausative usages through the stage of "impersonalization" that can be explained in terms of "objectivization of knowledge", i.e. knowledge without a knowing subject (for details, see Kulikov 2011).

The intransitive (anticausative) member of the opposition is typically inflected in the middle voice, while the transitive-causative forms are inflected in the active voice. Cf. kși 'perish, destroy': kșíyate 'perishes' (present IV) kṣináti (present IX) 'destroys'; jan 'be born, arise': jáyate 'is born' (present IV) jánati (present I), janáyati 'begets'; pu 'purify': pávate 'becomes clean, purifies oneself' (present I) punáti (present IX) 'purifies'. With some presents, the causative opposition is only marked by the diathesis (middle/active), as in námate 'bends' (intr.) námati 'bends' (tr.); svádate 'is sweet' svádati 'makes sweet'.

In the aorist system, the causative meaning is typically expressed by the reduplicated aorist, cf. $v r d h$ 'grow, increase' - ávivvrdhat 'made grow'.

There exist also some (rather weak) correlations between tense and transitivity; thus, for some verbs, predominantly intransitive (active) perfects may be opposed to predominantly transitive presents (e.g. tatấna 'has stretched' [intransitive] tanóti, tanuté 'stretches' [transitive-causative]; see Kulikov 1999b: 27 f.; Kümmel 2000: 208 ff.) and/ or appear in the same syntactic usage as the corresponding middle presents; cf. middle present pádyate 'falls' // active perfect papáda 'has fallen' (see Hoffmann 1976: 590; Kümmel 2000: $296 \mathrm{f}$., $370 \mathrm{ff}$. et passim).

Finally, there are also labile forms that can be used both transitively and intransitively. This is the case with many perfect forms (see Kümmel 2000), such as, for instance, 3sg.pf.med. vāvrdhé, 3sg.pf.act. vavárdha 'has grown (intr.)' 3sg.pf.act. vavárdha 'has increased (tr.)' as well as, more rarely, forms of other tense systems, such as svádate 'makes sweet (for oneself)' / 'is sweet' (for details, see Kulikov 2003, 2014b).

In early Vedic, we also find periphrastic causatives with the semi-auxiliary verbs $k r$ 'make' or $d h \bar{a}$ 'put' and dative infinitive (see Zehnder 2011b and 3.3.2.2).

\subsubsection{Constraints on (morphological) causative derivation}

In early Vedic, the -áya-causatives are only derived from (i) intransitives and (ii) from a few verbs of perception and consumption ( $d r s$ ' 'see', vid 'know', $p \bar{a}$ 'drink'), which 
Tab. 28.2: Growth of productivity of -yá-passives and -áya-causatives in Vedic

\begin{tabular}{|l|c|c|c|}
\hline & $\begin{array}{c}\text { early Vedic } \\
\text { (RV, AV) }\end{array}$ & $\begin{array}{c}\text { middle and late } \\
\text { Vedic (YV, Br.) }\end{array}$ & $\begin{array}{c}\text { post-Vedic } \\
\text { (Sūtras, Ep.) }\end{array}$ \\
\hline \begin{tabular}{l|c|c|} 
hypercharacterized causatives \\
in -apaya-
\end{tabular} & - & - & + \\
\hline $\begin{array}{l}\text { passives of causatives of } \\
\text { transitives }\end{array}$ & - & - & + \\
\hline causatives of transitives & - & + & + \\
\hline $\begin{array}{l}\text { passives of causatives } \\
\text { of intransitives }\end{array}$ & - & + & + \\
\hline causatives of intransitives & - & + & + \\
\hline $\begin{array}{l}\text { passives of non-causative } \\
\text { transitives }\end{array}$ & + & + & + \\
\hline
\end{tabular}

can be constructed either with the accusative DO or with some other oblique case objects (in the locative, genitive, etc.). That is, morphological causativization is only possible for intransitives and "intransitive/transitives" (I/T) in Jamison's (1983) terminology, or for "semantically intransitive verbs" (in terms of a more semantically-oriented approach to transitivity; see Kulikov forthcoming.a).

Periphrastic causatives with $k r$ or $d h \bar{a}$ can be derived from transitives and thus, according to Jamison (1983: 38), are in complementary distribution with the intransitivebased morphological -áya-causatives. Cf. nas krdhi samcákṣe bhujé asyái (RV 1.127.11) 'make us see and enjoy this' $\sim$ cakșaya- ${ }^{t i}$ 'reveal' = 'make appear' (but see also Kulikov 2008: 255, with fn. 28, for other possible syntactic analyses of this passage).

Causatives of transitives first appear in middle Vedic, cf. $k r$ 'make' - kāráyati $(\mathrm{Br} .+)$ 'cause to make', $h r$ 'take, carry' - hāráyati $\left(\mathrm{YV}^{\mathrm{p}}+\right)$ 'make take, make carry' etc. (see Thieme 1929; Jamison 1983: 186 f.; Hock 1981: 15 ff.). Finally, in late Vedic and postVedic texts (Sūtras, Epic Sanskrit) the productivity of the -áya-causatives further increases, and, from the late Sütras onwards, we find the earliest attestations of a new formation, hyper-characterized causatives in -āpaya-, such as aś 'eat' - aśāpayati (MānGS) (opposed to the simple causative áśayati [Br.+]), kșal 'wash' - kșālāpayīta (Sū.) (opposed to the simple causative kșālayati [Br.+]). In some Middle and New Indo-Aryan languages such forms have eventually given rise to double causatives.

The increasing productivity of the $-y a$-passives in later texts neatly parallels the growth of productivity of the -áya-causatives, as shown in Table 28.2.

\subsubsection{The syntax of causative constructions}

Causative derivation adds the meaning 'cause' to the base proposition and a new actor to the semantic structure of the initial clause. The causer obligatorily takes the Subject position. Accordingly, the initial Subject, or causee, is ousted from the Subject position 
and demoted down the hierarchy of grammatical relations $(\mathrm{S}>\mathrm{DO}>\mathrm{IO}>\mathrm{Obl})$. In early Vedic, where the -áya-causatives and reduplicated causative aorists can only be derived from intransitives (as well as from a few I/T verbs), the causee can only be encoded with the accusative, as in RV 10.94.9 indro vardhate 'Indra increases' - RV 8.14.5 yajñá indram avardhayat 'the sacrifice made Indra increase'.

In middle Vedic, we find first causatives derived from transitives. Their causees can surface either in the accusative (ŚB 2.3.3.16 sáinam svargám lokám sám àpayati 'she makes him reach the heavenly world') or in the instrumental (TS 5.4.9.3 áhnaivắsmai rátrim prá dāpayati 'he makes the day to give him the night'). The latter type of casemarking is more common in causative constructions where the causee preserves a higher degree of volitionality and more control over the situation; for details, see Hock (1981, 1991).

3.3.3. Transitivizing (applicative) derivation has only marginal status within the Vedic system of the valency-changing categories; see 3.1.3 above.

\subsubsection{Reflexive}

\subsubsection{Reflexive and middle}

The term "reflexive" is often employed to denote one of the functions of the middle diathesis (alongside the passive, the self-beneficent, and others). However, forms with middle inflexion are rather rarely employed in reflexive usages in the strict sense of the word, such as RV 2.33.9 pipiśe hiranyaih '[Rudra] has adorned himself with golden decorations'. In many cases such middle intransitive forms, traditionally called "reflexives" (see, e.g., Speijer 1896: 48; Gotō 1996: 27, 49 et passim), do not instantiate reflexives in the strict sense of the term (see, e.g., Gonda 1979: 49) and should rather be qualified as anticausatives (alternatively, they might be called "weak reflexives"), cf. bhr 'bring': bhárate 'moves' (= *'brings oneself'), $p \bar{r}$ 'fill': púryate 'becomes full, fills oneself'. The non-passive intransitives of this type often exhibit idiomatic semantic changes, cf. śap 'curse': śápate 'swears'; śísíte (RV 1.36.16) 'is too nimble' $\leftarrow$ *'sharpens oneself'.

\subsubsection{The system of reflexive morphemes}

More commonly, the reflexive function sensu stricto is rendered in Vedic by derivatives of the three following roots: svá-, tanú- and àtmán- (tmán-). See Delbrück (1888: $207 \mathrm{ff}$., 262 f.); Oertel (1926: 184 ff.); Wackernagel (1930: 478 ff., § 237; 488 ff., § 240); Gonda (1979: 49); Vine (1997); Pinault (2001); Hock (2006); Kulikov (2007); and, with some criticisms contra the last three, Hettrich (2010). 


\subsection{Reflexive pronoun tanú-}

\subsection{Reflexive usage}

The reflexive pronoun $\tan \hat{u}$ - has developed from the substantive meaning 'body' and is well-attested in this grammaticalized usage in the RV, as in RV 1.147.2d vandấrus te tan $_{u}$ vàm vande agne 'As your praiser, I praise myself, o Agni.' In some cases it is nearly impossible to draw with accuracy the distinction between the reflexive and non-reflexive ('body') meanings: both interpretations are perfectly appropriate in the context, as in RV 10.54.3cd yán mātáram ca pitáram ca sākám ' ájanayathās $\tan _{u} v a ̀ h h ~ s_{u} v a \bar{y} y \bar{a} h$ '... since you produced (your) mother and (your) father together from your own body / from yourself.'

\subsection{Emphatic usage}

Next to the reflexive usages proper, the Vedic reflexive pronouns can be employed in emphatic usages, i.e. as emphatic reflexive, or intensifier, signaling the fact that its referent is somewhat unexpected in the role where it appears (cf. two usages of English -self: Peter saw himself in the mirror $\sim$ Peter drew this picture himself). In the more common adverbial case pattern we find the instrumental forms (as in RV 6.49.13 quoted in 3.3.4.3.1 below). The nominal pattern is attested, for instance, with accusatives and datives, as in AV 1.13.2 = RVKh. 4.4.2 mrḍ́yā nas tanúbhyo / máyas tokébhyas krdhi 'Be gracious towards ourselves, make pleasure for [our] offspring.'

\subsection{Reflexive pronouns ātmán- and tmán-}

\subsection{Reflexive usage}

The reflexive usage of atmán- becomes common after the RV, but is still in competition with $\tan \bar{u}$ - in the AV. In Vedic prose, àtmán- completely ousts tan $\dot{u}$-; see Delbrück (1888: $207 \mathrm{ff} ., 262 \mathrm{f}$.); Wackernagel (1930: $489 \mathrm{ff} .$, \$240b); and, especially, a brief survey in Oertel (1926), with a rich collection of examples.

\subsection{Emphatic usage}

The emphatic usage is attested for ätmán- from the AV onwards, cf. TS 1.7.3.3 táto devà ábhavan párắsurā yásyaivám vidúșo 'nvāhāryà āhriyáte bhávaty ātmánā párāsya bhrátrvyo bhavati 'Then the gods prospered, the Asuras perished. He, who, knowing thus, performs the Anvāhārya-rite, prospers himself, his rival perishes.'

In contrast to ätmán-, the more archaic stem variant tmán- already occurs in emphatic usage in the early RV. Its instrumental appears in the very frequent regular form tmána (63 attestations in the RV) and in the form tmánya (built on the stem tmáni- or tmánya-, of unclear origin; see Macdonell 1910: 206, fn. 11), which occurs in the late RV 
(1.188.10, 10.110.10) and in the late mantras (VS $20.45=\mathrm{TB}^{\mathrm{m}} 2.6 .8 .4$ etc.), cf. RV 10.110.10 upávia srja tmányā 'Release [the sacrificial animal] yourself.' The locative is attested in two forms as well: tmáni $(2 \times)$, and the more archaic variant with the zero ending, tmán (5×), as in RV 6.68.5 sá í sudánuh svávām̆ ... índrā yó vām varuna dấśati tmán 'Only the one who honours you himself, o Indra, o Varuna, is rich in gifts, rich in protection ...'

\subsubsection{The syntax of reflexive constructions}

\subsection{Case patterns}

The case of the reflexive pronoun is determined by its syntactic function in the clause structure (direct object $=$ accusative, indirect object $=$ dative, etc.). The case-marking of the emphatics is regulated by more complex rules and depends, in particular, on the position of its antecedent and some other syntactic and semantic parameters. Typological studies on emphatic reflexives distinguish between adnominal and adverbial uses. In the former use, emphatics surface as adjuncts to noun phrases, while in the latter use, they are adjoined to verbal phrases and fill the position of an adverbial. Both tanú - and (a) tmán-, when employed as emphatics, prefer the adverbial uses, which display two syntactic patterns determining their case: (i) "nominal pattern": the pronoun copies the case of its antecedent noun phrase; and (ii) "adverbial pattern": the pronoun surfaces in the case which is used adverbially, irrespectively of the case-marking of the corresponding noun. In the RV, we find in the adverbial pattern the instrumental forms of tan $\bar{u}$ (e.g. inst.sg. tanvà) and some oblique case forms of tmán- (instrumental, locative; see 3.3.4.2.2.2), as in RV 6.49.13d rāyá madema $\tan _{u} v \overline{\bar{a}}$ tánā $c a$ 'May we enjoy wealth ourselves and in (our) offspring'.

\subsection{Number agreement}

The Vedic reflexives originate in non-pronominal substantives ('body' and 'soul'), inheriting their full paradigm. In Early Vedic, both tan⿳亠丷- and ātmán- (but not tmán-, which only shows a few singular forms) agree in number with the antecedent noun both in the reflexive (see below) and emphatic usages, cf. RV 3.1.1 ... agne tan $_{u}$ vàm juṣasva '... $\mathrm{O}$ Agni, enjoy yourself!'; RV 10.8.3 árușìr ... r. rtásya yónau tan ${ }_{u}$ vò juṣanta 'The reddish [flames] ... enjoy themselves in the womb of order.'

\subsection{Heavy reflexive constructions}

In early Vedic, the reflexive $\tan \bar{u}$ - sometimes occurs constructed with the pronominal adjective svá- 'own' (feminine stem $s v \bar{a}-$ ), as in RV 7.86.2a utá sváyā tan $v$ à̀ sám vade tát 'And I discuss it with myself' (see Pinault 2001: 187; Hock 2006), RV 10.8.4cd rtấya saptá dadhiṣe padáni ' janáyan mitrám tan tà $_{u}$ vắyai 'You (= Agni) placed seven 
steps for order, producing a friend for yourself'. The root svá-also appears in the isolated form svayám '(one)self', which behaves as a nominative (-ám may have been borrowed from the nominative form of the $1^{\text {st }}$ person pronoun ahám 'I' or from the demonstrative nom.sg.m. ayám; see Wackernagel 1930: 480 ff.), as in RV 6.51.7d svayám ripús tan rìrișisța 'Let the deceiver hurt himself (on his own).'

Both svá- and svayám additionally emphasize the coreference of the object with the subject (Gonda 1979: 49; Pinault 2001: $188 \mathrm{f}$.), pointing to the unexpected character of the reflexive situation and contrasting it with the non-reflexive situation (the deceiver is hurt by himself, not by others, etc.). The opposition between the emphasized (sváa-/ svayám tan $\bar{u}-)$ and non-emphasized (tan $\bar{u}-)$ reflexives is likely to represent the same distinction as that between (morphologically) complex (heavy) and simple reflexives, which can be illustrated by such parallels as Dutch zichzelf $\sim$ zich or Russ. sam sebja, samogo sebja $\sim$ sebja.

In the language of the Atharvaveda, alongside the collocation $s v \bar{a}-\tan \dot{\bar{u}}-$, we find constructions where tan $\bar{u}$ - and àtmán- co-occur in the same case form, as in AVP 4.10.4 adbhir ātmānam tanvam śumbhamānā / grhān prehi 'Adorning yourself/[your] own body with waters, go forth to the homestead'; AVŚ 1.18 .3 yát ta ātmáni tanvà̀m ghorám ásti / yád vā kéśeșu ... 'Whatever is terrible in yourself/in your own body, whatever in [your] hairs ...' Given the obvious parallelism of àtmānam tanvam śumbhamāna with

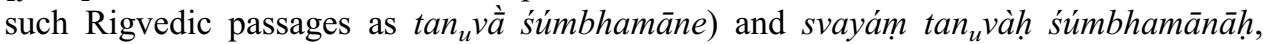
àtmán- should be qualified in such constructions as a functional equivalent of $s v \bar{a}-$ in the collocation $s v \dot{\bar{a}-}$ tan $\dot{\bar{u}}$-, which either means 'own body', or is employed as a heavy reflexive pronoun (see Kulikov 2007 for details).

\subsubsection{Reciprocals and sociatives}

\subsubsection{The system of reciprocal morphemes}

The reciprocal meaning ('each other') can be expressed either morphologically, i.e. by means of bound morphemes, or periphrastically (analytically) (see Krisch 1999; Kulikov 2007a). The morphological reciprocals include: (i) rare non-characterized middle forms; (ii) middle forms with the preverb $v i$-; and (iii) spatial reciprocals with the preverbs $v i$ and sám-. Periphrastic (analytic) reciprocals include (iv) reciprocal constructions with the adverb mithás 'mutually'; and (v) reciprocal constructions with the polyptotic pronoun anyó-(a)nyám 'another-another', as well as, in post-Vedic Sanskrit, constructions with two other polyptotic reciprocal pronouns (probably built on the model of anyó(a)nyám), itaretara- (BĀU+, rare) and paras-para- (ŚrSū.+).

\subsubsection{Morphological reciprocals}

\subsection{Non-characterized middle forms}

Examples of non-characterized middle forms are: mith 'be inimical' - na methete (RV 1.113.3) '(the day and night) are not inimical to one another'; $t \bar{r}$ 'surpass, overrun' tarete (RV 1.140.3) '(both parents) overrun one another'. 


\subsection{Middle forms with the preverb ví-}

$v i$-reciprocals are mostly attested for verbs of hostile activities and communication or speech. They include two major classes. "Canonical" reciprocals suggest a reciprocal relation between the subject and direct object, cf. dviṣ 'hate' - ví-dviṣ (middle) 'hate each other, be inimical', han 'kill, destroy' - vi-han (middle) 'kill, destroy each other'. "Indirect" reciprocals denote a symmetric relation between the subject and non-direct (typically, indirect) object, cf. vad 'speak' - (ví-) vad (middle) 'discuss with each other, contest, argue'; bhaj 'make share, distribute, give smth. (acc.) to smb. (dat.) as a share' vi-bhaj (middle) 'distribute smth. (acc.) among each other, share with each other'; $d \bar{v} v$ 'play' - vi-dīv (middle) 'play for smth. (acc.) with each other'.

Both (i) morphological causatives (reduplicated aorist) and (ii) present passives with the suffix $-y a$ - are possible (albeit very rare) on the basis of $v i$-reciprocals, cf. (i) AVP 2.58.1 vidveșaṇam kilāsitha 'yathāinau vy-adidvișah 'Verily, you are (mutual) hostility/causing (mutual) hostility, for you have made them (both) inimical to each other (lit. made hate each other)' (a verse addressed to a magic amulet); and (ii) MS 2.2.13:25.13 sátvāno gấ ichanti. yád eté tandulā vi-bhājyánte, sátvāno vấ etá eștấro 'bhiroddhấra evá 'The warriors seek for cows. [The fact] that these grains are distributed [by warriors among each other] is, verily, [due to the fact that] these warriors are seekers

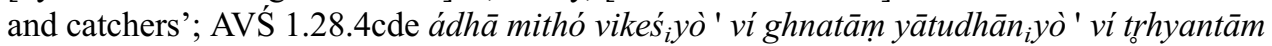

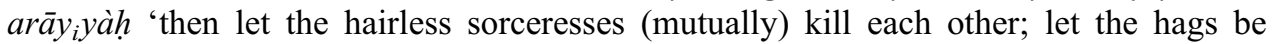
crushed (killed) by each other' (see Kulikov 2012a: 105 f., 160 ff.). From the typological point of view, this latter type is extremely rare. While the indirect reciprocal derivation retains the initial direct object, so that passivization remains possible, a canonical reciprocal must be intransitive by definition, which, at first glance, rules out passivization. Perhaps this construction was brought to life by some particular stylistic techniques of poetic texts.

\subsection{Spatial reciprocals with the preverbs ví 'apart' and sám 'together'}

Spatial reciprocals with $v i$ and sám denote separating and joining, respectively. They are much more productive than reciprocals proper with the preverb vi (see Kulikov 2007a: $723 \mathrm{ff}$.; Casaretto 2011b). In contrast with vi-reciprocals, they can take both middle and active endings: middle forms are employed as subject-oriented reciprocals (i.e. refer to separating/joining of the participants denoted by the subject: 'come together' etc.), while active forms can be employed either as subject-oriented reciprocals (cf. vi-yánti '[they] go apart'), or, more commonly, as object-oriented reciprocals (i.e. refer to separating/ joining of the participants denoted by the object: 'bring together' etc.). However, some of the middle (and, more rarely, active) sám-reciprocals should be qualified as sociatives, meaning 'perform the activity expressed by the base verb together', rather than spatial reciprocals (cf. trp 'rejoice' - KB 12.6.16 sarvā devatāh sam-trpyante 'all deities rejoice together'). In some cases, the distinction between these two types cannot be drawn with accuracy.

The system of meanings expressed by the preverbs vi and sám (as opposed to the corresponding simplex verbs) can be schematically represented in the following table: 
Tab. 28.3: Vedic reciprocal and sociative meanings expressed by ví and sám

\begin{tabular}{|l|l|l|}
\hline \multicolumn{1}{|c|}{ Active } & \multicolumn{1}{|c|}{ Middle } \\
\hline$(\emptyset)$ & $\begin{array}{l}\text { transitives } \\
\text { (e.g. bharati 'X carries Y'); } \\
\text { intransitives } \\
\text { (e.g. gacchati 'X comes'); } \\
\text { etc. }\end{array}$ & $\begin{array}{l}\text { symmetric predicates (including some lexical } \\
\text { reciprocals), reflexives, .. } \\
\text { (e.g. bharate 'X carries oneself, moves' [ref.]; } \\
\text { 'X carries Y for oneself' [self-benef.]) }\end{array}$ \\
\hline sám & $\begin{array}{l}\text { object-oriented spatial reciprocals } \\
\text { of joining } \\
\text { (e.g. sám bharati 'X carries Ys } \\
\text { together'); } \\
\text { (sociatives) }\end{array}$ & $\begin{array}{l}\text { subject-oriented spatial reciprocals of joining } \\
\text { (e.g. sám gacchante 'Xs come together'); } \\
\text { sociatives } \\
\text { (e.g. sám pibante 'Xs drink together') }\end{array}$ \\
\hline $\boldsymbol{v i}$ & $\begin{array}{l}\text { object-oriented spatial reciprocals of } \\
\text { separating (e.g. ví bharati 'X spreads } \\
\text { Ys asunder, distributes Ys'); } \\
\text { subject-oriented spatial reciprocals of } \\
\text { separating (e.g. vi-yánti '(they) go } \\
\text { apart') }\end{array}$ & $\begin{array}{l}\text { subject-oriented spatial reciprocals of } \\
\text { separating } \\
\text { (e.g. ví gacchante 'Xs go asunder, separate'); } \\
\text { reciprocals proper } \\
\text { (e.g. ví jayante 'Xs overcome each other') }\end{array}$ \\
\hline \multicolumn{2}{|l}{} \\
\hline
\end{tabular}

\subsubsection{Periphrastic (analytic) reciprocals include}

\subsection{Reciprocal constructions with the adverb mithás 'mutually'}

A more common reciprocal marker in early Vedic is the adverb mithás (with the sandhi variants mitháh, mithó-) 'mutually', which is almost exclusively constructed with middle verbal forms. In the RV, mithás-reciprocals are attested with some 15 verbs and can form reciprocals of different syntactic types. These include (i) "canonical" reciprocals; cf. $h i$ 'urge, impel' - RV 10.65.2 mithó hinvānă 'impelling each other'; pū 'purify' - punāné mitháh 'purifying each other [of earth and heaven]'; (ii) possessive reciprocals; cf. rih 'lick' - RV 8.20.21 rihaté kakúbho mitháh 'they lick each other's backs' (as bulls do). (iii) It can also be (pleonastically) used with symmetric predicates and morphological middle reciprocals (including reciprocals with sám-), as in sprdh 'compete' sám ... mitháh pasprdhānấsah 'competing with each other'. mithás does not occur in constructions with "indirect" reciprocals.

\subsection{Reciprocal constructions with the polyptotic pronoun anyó (a)nyám}

Reciprocal constructions with the reciprocal pronoun (RP) anyó (a)nyá-represents the iteration of the pronominal adjective anyá- 'another, one of a number, the other' and is the most frequent type of the Sanskrit reciprocals. The pronoun anyó (a)nyá- can express reciprocal relations between the subject and any other argument, including the direct object, indirect object, possessor noun, etc. Accordingly, the second part may appear in different case forms: accusative (= "canonical" reciprocals), dative (= "indirect" reciprocals), genitive (= possessive reciprocals), locative, and instrumental. 
From the early Vedic period onwards, we observe both the increase of productivity of anyó (a)nyá- and its morphological evolution from a free combination of words into a grammaticalized pronoun (Wackernagel 1905: 322 f.; Kulikov 2007a, 2014a).

I. Early Vedic (the early Rigveda). In the earliest documented period, i.e. in the RV, reciprocal constructions with anyó ... anyá- are still rare $(5 \times$ in $\mathrm{RV})$. It is not yet grammaticalized as a single reciprocal marker, its constituent parts remaining autonomous lexical units, which can be separated by other word(s). Both parts of the "quasi-pronoun" agree in number and gender with the antecedent noun. The verbal form agrees with the first part of the RP, and thus appears in the singular, in accordance with the syntactic pattern 'RM1:NOM S:GEN.NON-SG RM2:ACC V:SG' (where RM1 and RM2 stand for the first and second part of the RP), as in RV 7.103.3-4 anyó anyám úpa vádantam eti / anyó anyám ánu grbhṇat $t_{i}$ enor 'one (frog) goes to the call of another; one of the two supports another'.

II. Late early Vedic (late books of the Rigveda, Atharvaveda). From the end of the early Vedic period onwards, in the late Rgveda and Atharvaveda, we find another pattern, S:NOM.NON-SG RM1:NOM (...) RM2:ACC V:NON-SG, with the verb in the non-singular (plural or dual) form, as in AVŚ 12.3.50a sám agnáyo vidur anyó anyám 'The fires know each other'. Rarely, both parts of anyó ... anyá- may appear in the plural: AVP 5.10 .7 hatāso anye yodhayant ${ }_{i}{ }^{+}$anyāms ... 'Those which are hit incite one another to fighting' (lit. 'make fight one another'; said of alcohol-drinkers).

III. Middle and late Vedic. Vedic prose attests a number of features that testify to a further grammaticalization of anyò'nyá-: (i) The parts of the RP anyò'nyá- cannot be separated by other words. (ii) Although in most accentuated texts both parts of the RP bear accents (anyò- ${ }^{a}$ nyá-; see Wackernagel 1905: $322 \mathrm{f}$.), we also find a single accent (on the first component of the pronoun), attested in TB 1.3.2.1 anyò-nyasmai náatișthanta 'They (the gods) did not adhere to each other.'). (iii) The gender agreement of the constituent parts of the RP follows one of the following two patterns: (a) anya-[m/ $\mathrm{n} / \mathrm{f}]$-anya- $[\mathrm{m} / \mathrm{n} / \mathrm{f}]$, or (b) anyó $[\mathrm{m}]-$ anyá- $[\mathrm{m} / \mathrm{n} / \mathrm{f}]$. In constructions of type (a), both parts of the RP agree in gender with the nominal antecedent. This pattern is attested only in very few texts, in particular, in the relatively late Jaiminīya-Brāhmaṇa, as in JB 1.117:12 prajāpatih prajā asrjata. [...] tā aśanāyantīr anyā-nyām ādan 'Prajāpati created the creatures. [...] Being hungry, they ate each other.' Most texts have generalized the masculine form of the first part of the RP (anyo-) and thus follow the agreement pattern (b), as in PB 24.11 .2 prajāpatih prajā asrjata. tā avidhrtā asañjānānā anyo-nyām ādan 'Prajāpati created the creatures. They, not being kept apart, not agreeing (with each other), ate each other.'

IV. In late Vedic and post-Vedic Sanskrit anyo'nya- is further grammaticalized: (i) Neither part of the RP agrees in gender or number with the antecedent; the masculine singular form (nominative anyo-, accusative anyam, etc.) becomes generalized, as in Rām. 2.53.10 anyo-nyam (*anyānyām) abhivīksante ... ārtatarāh striyah 'The confused women look at each other'. (ii) anyo'nya- can be used with non-subject antecedents, for instance, in object-oriented reciprocal constructions, as in ŚB 11.6.2.2 gharmấv evá ... anyò-'nyásmin (*anyám-anyásmin) juhomi 'I pour both gharma-oblations, one into another', where RM2 receives the locative case as the oblique argument of the verb juhomi '(I) pour into', but RM1 does not agree in case with its accusative antecedent gharmáu 'oblations'. (iii) In Epic Sanskrit, we also find the fossilized (adverbial) form anyonyam, as in Rām. 5.89 .52 teșām sambhāṣa-mānāānām anyo-nyam ... (not *anyasyānyena) '... of them, conversing with each other ...' 


\section{Non-inflectional words}

\subsection{Preverbs/adpositions}

\subsubsection{Preverbs and tmesis}

Vedic has a number of semi-autonomous verbal morphemes (prefixes), traditionally called preverbs. In early Vedic, the preverbs behave as free morphemes (except in subordinate clauses and with non-finite forms) and are often preposed to the verb. In the later language, their separation from the verb (tmesis) becomes rare or exceptional and, by the end of the Vedic period, virtually impossible (see Renou 1933). The main preverbs include (see, for instance, Whitney 1889: $396 \mathrm{ff}$.; Renou 1952: $316 \mathrm{ff}$.): áti 'across, beyond, over', ádhi 'above, over, (up)on', ánu 'after, along', antár 'between, among, within', ápa 'away', ápi 'unto', abhi 'to(wards), over, against', áva 'down', à 'to(wards), at', úd 'up', úpa 'to, near', ni 'down', nís 'out', párā 'away', pári '(a)round, about', prá 'forward, forth', práti 'back, in return', vi 'apart, asunder' and sám 'together'. See brief surveys, for instance, in Whitney 1889: 396 ff.; Renou 1952: 316 ff.; Gotō 2013: 144 f. On individual preverbs, see, in particular, Dunkel 1982 (on $\bar{a}$ ); Dunkel 2014, s.vv., as well as the series of papers "Syntax und Wortarten der Lokalpartikeln des/im Rgveda" by Antje Casaretto, Heinrich Hettrich and Carolin Schneider, such as Hettrich 1991 (ádhi); Hettrich 1993 (antár); Casaretto 2011a (ánu); Casaretto 2011b (ví); Schneider 2009 (ni) and others.

\subsubsection{Preverbs vs. adpositions}

The majority of morphemes listed in 4.1.1 can also be used as adpositions (that is, as post- or, very rarely, as prepositions). Exceptions are $u ́ d, n i ́$, párā, ví and sám which can only be used as preverbs. For early Vedic, when the preverbs still exhibit considerable autonomy, the distinction between these two usages (adpositions vs. preverbs) cannot be drawn with accuracy in some cases. Thus, for RV 9.19.3 vŕșā [...] yónim ä́-asadat 'The bull ... has sat down upon the lap' two syntactic analyses are possible:

(i) as a compound verb constructed with an accusative: [yónim] [⿳亠丷a-asadat]), and

(ii) as a simplex verb constructed with a postpositional phrase: [yónim á-] [-asadat]).

On a delicate semantic distinction that can be found between adnominal (adpositional) and adverbal usages such as ádhi rátham tiṣthati / ádhi tișthati rátham 'he mounts the chariot', see Hettrich (1991: $39 \mathrm{f}$.).

There are also some non-neutral word orders, which favor one of the two analyses, as a postposition or as a preverb. Thus, in the case of the "Verb + Noun + Preverb" order, as in RV 9.64.17 índavah ágmann rtásya yónim á 'The drops have come upon the lap of the (cosmic) Order', where the morpheme $\frac{a}{a}$ immediately follows the noun phrase, it is typically treated as a postposition (see, e.g., Grassmann 1873: Sp. 169). By contrast, in the case of the 'Preverb + Noun + Verb' order, as in RV 9.97.45 (á yónim ványam asadat 'He (sc. Soma) has sat upon the wooden lap'), the same morpheme is usually taken as a preverb (see, e.g., Grassmann 1873: Sp. 1455 f.).

For the use of cases with adpositions, see 2.1.3. 


\subsection{Adverbials}

The class of adverbials includes, foremost, (i) frozen case forms of nominals (substantives and adjectives) that can be used adverbially (cf. acc. náktam 'by night', inst. dívā 'by day', abl. dū $r_{\bar{a}} t$ 'from afar', etc.) and (ii) denominal formations with adverbial suffixes, such as $-d h \bar{a}$ 'in N ways', -vat (manner; see Pinault 1985a), -tas 'from', etc; see Gotō 2013: $145 \mathrm{ff}$. for a survey.

\subsection{Particles}

Particles can be classified in accordance with their position in the sentence, as (i) those placed immediately after the word with which they are connected: $c a$ 'and', $v \bar{a}$ 'or', evá 'verily' etc.; (ii) those which are (usually) placed immediately after the first word of a sentence (or clause), i.e. in Wackernagel's position: $i d$, $u$, hi, sma, ha, etc.; and (iii) sentence-initial particles, which may be placed at the beginning of a sentence: utá, átha, etc. The first two classes include both clitic and accented particles. The semantics or function of some particles is quite difficult to determine; many of them can be employed for emphasis or as connectors. Thus, the connective particle $u$ is especially common (i) in anaphoric chains with pronouns, as in RV 10.102.10b yám yuñjánti tám ${ }_{u} v$ á sthappayanti 'The one whom they (usually) yoke, that one do they make climb (the chariot)'; (ii) with non-coreferential iterations of relative and interrogative pronouns, as in RV 6.9.6d kím svid vakṣyámi kím u nú maniṣye 'What shall I say, and what shall I now think?'; and (iii) as a consecutive clause connector; cf. RV 10.27.7a ábhūr ${ }_{u} v$ áukșìr $v_{i} y$ ù áyur ānat 'You have come into existence, and you have grown, and you have obtained a (full) lifetime'. For an exhaustive description of this and several other particles, see Klein (1978, 1985); Dunkel 2014 (s.vv.).

There are also two negative partricles, ná and $m \dot{a}$ (almost exclusively employed with injunctives), and two comparative particles, ná (mostly after consonants, as in áśvo ná 'like a horse' = áśvah + ná) and iva (mostly after vowels, as in rá́jeva 'like a king' = rá̀jā + iva); see Pinault (1985b, 1995-1996).

\section{Word order}

The unmarked word order is SOV, but other, non-neutral, word orders are fairly frequent, especially in metrical texts. Some of them may have certain emphatic functions and/or appear in marked pragmatic situations. Thus, the clause-initial position of the verbal phrase may be used for expressing contrast, in particular, in situations where the subject is the focus, rather than the topic of a clause, as in RV 5.54.2 váśati tritáh. svárant ${ }_{i} y$ ápah 'Trita roars. The waters resound' (see, in particular, Schäufele 1991; Viti 2007). The rare OSV word order may appear in cases of the object overruling the subject in the Animacy hierarchy (e.g. inanimate S/Agent :: human DO/Patient), as in RV 1.11.1ab indram viśsa avīvrdhan' samudrávyacasam gírah 'All prayers have increased Indra, (who is equal) to the whole ocean' (see Viti 2009, 2010). 
The substantive is preceded by the adjective and the attributive (e.g. possessor's) genitive and followed by the apposition (cf. sómo rắjā 'Soma the King').

In nominal sentences of the type $A$ is $B$, the subject is typically preceded by the predicate, as in RV 1.4.2c godá íd reváto mádah 'The intoxication of the rich one furnishes cows (lit. is cow-giving)'.

\section{Sentence syntax and complex sentences}

\subsection{Non-finite predication}

\subsubsection{Syntax of participles and nominalizations}

While participles (syntactically, deverbal adjectives; see Lowe 2015) typically preserve the syntactic pattern of the finite verb, deverbal nouns usually replace the nominative and accusative of the core arguments (S and DO) with genitive (subjective and objective genitive with nominalizations). The deverbal nouns in -tar-/-tri- occupy, in a sense, an intermediary position between these two syntactic classes of deverbal formations: the hysterodynamic -tar-nouns typically replace the accusative of the DO with genitive (as in RV 6.23.10d indro rāyó viśvávārasya dātá 'Indra is the giver of wealth desired by all'), while the acrostatic -tar-nouns mostly preserve the accusative marking of DOs (as in RV 6.23.3 dátā vásu stuvaté 'the giver of goods to the praiser'), although we also find rare examples of constructions with genitive DOs, cf. RV 1.124.5 gávām jánitrī 'the mother of the cows'. On the syntax of the nouns in -tar-, see Tichy (1995).

\subsubsection{Converbs (absolutives, gerunds)}

For the morphological inventory of converbs (absolutives, gerunds), see Gotō (this handbook: 5.8.5). For a detailed analysis of the syntax of converbial, or gerundial, constructions, see Tikkanen (1987: $141 \mathrm{ff}$.). The most important aspect of the syntax of converbs is the choice of the controller of the reference of their subject. Most commonly (especially in the early language), the subject of a converb is coreferential with the (nominative) subject of the main predication, as in RV 10.68 .3 bŕhaspátih párvatebhyo vitúryā ' nír gá $\bar{u}$ pe 'Brhaspati, having penetrated through the mountains, strewed out the cows' or ŚB 5.2.3.1 sárvam parigŕhya sūyā iti 'Having encompassed the all, may I be consecrated'. Rare are examples of converbial constructions whose subject is coreferential with a non-canonically marked (oblique) subject (in the accusative, instrumental, dative, genitive) or even possessor of the main predication, as in RV 10.34.11a stríyam drștvá̀ya kitavám tatāpa 'Upon seeing (his) woman, it distresses the player'. Instances of converbs referentially controlled by the instrumental argument ("passive agent") of a nominal passive constructions with the -ta-/-na-adjective in later language (Epic and Classical Sanskrit) must betray the earliest features of the ergative construction, which develops in the Middle and New Indo-Aryan period. 


\subsubsection{Syntax of infinitive constructions}

Another class of forms used for secondary (non-finite) predication includes a variety of infinitives; for a morphological survey, see Gotō this handbook: 5.8.1; for a syntactic study as well as classificatory and terminological issues (infinitives or verbs of purpose? [T. Zehnder]), see Keydana (2013); Zehnder (2011a, 2016). Infinitive constructions usually preserve the case marking of the corresponding finite predication, but some dative infinitives may "attract" the dative form, replacing the original accusative with the dative, as in RV 6.1.1 viśvasmai sáhase sáhadhyai '... in order to overpower any power'; RV 5.31.4 áhaye hántavấ $u$ 'in order to kill the serpent'.

On the passive syntax of infinitives in -tavái (-tave), see 3.3.1.1.

\subsubsection{Absolute constructions}

As in many ancient Indo-European languages, there are absolute constructions, with the verb appearing in a participial form agreeing with the subject. These include an absolute locative construction (as in TS 6.6.9.2 somé hanyámāne yajñó hanyate 'When soma is being killed, the sacrifice is being killed') and a much rarer absolute genitive construction; see Keydana (1997); Ruppel (2013: 127 ff.).

\subsection{Complex sentences}

\subsubsection{Coordination}

Simple clauses can be joined into coordinating structures either without using any special morpheme (conjunction), or with coordinating particles (clause connectors), the main of which include utá, átha, átho (= átha-u), cf. RV $3.31 .7 \mathrm{~cd}$ sasána máryo yúvabhir makhasyánn ' áthābhavad ángirāh sadyó árcan 'The young hero, battling, conquered together with the young men. And then the Angiras immediately became a singer' (for their comprehensive syntactic description, see Klein 1985: 65 ff.).

\subsubsection{Subordination}

An exhaustive treatment of subordination (hypotaxis) in Vedic is given in Hettrich (1987); see also Viti 2008.

\subsubsection{Relative sentences}

The canonical type of relative sentence consists of the subordinate clause (SC) with the relative pronoun $y a$ - (typically occupying clause-initial position) and main clause (MC) with the correlative pronoun $t a ́$-/sá-. The target noun of relativization $\left(\mathrm{N}_{\mathrm{R}}\right)$, or the antecedent of the relative clause (Nukleus in terms of Hettrich 1987: $527 \mathrm{ff}$.), is typically 


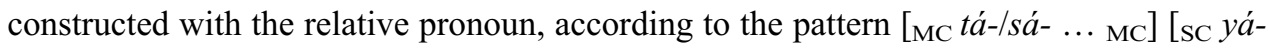
$\mathrm{N}_{\mathrm{R}} \cdots \mathrm{sC}_{\mathrm{S}}$ ] (or with the reverse order of clauses). More rarely, the antecedent is constructed with the correlative pronoun. Cf.: RV 1.41.5 yám yajñám náyathā nara 'ádityā rjúnā pathă / prá vah sá dhìtáye naśat 'The sacrifice which you, Ādityas the men, lead on a right way, will come to you according to your thought'; RV 10.184.3bc yám nirmánthato aśvínā / tám te gárbham havāmahe 'The embryo which the Aśvins rub out we will call for you'. The relative sentences with the postposed relative clauses slightly prevail in Vedic (see Holland 1996). For repetitive sequences of relative clauses, quite common in the language of the RV, see Klein (2004-2005).

\subsubsection{Other types of subordinate sentences}

There is a variety of other types of subordinate complex sentences, which are formed by means of a number of conjunctions. Most of these conjunctions are derived from the stem of the relative pronoun yá- (or represent some fossilized forms of its paradigm). These include: yád ( $\leftarrow$ nom.-acc.sg.n of yá-) 'if, when; because of; so that', yáthā 'as, like; in order/so that'; yátra 'where; when', yádi 'if', céd 'if'. The syntax of such subordinate clauses often requires a non-indicative mood, viz. subjunctive or (from middle Vedic onwards) optative, as in RV 1.27.13c yájāma devấn yádi śaknávāma 'We will worship gods if we can' (subjunctive both in the main and subordinate clause), RV 5.3.10ab bhū́ri nấma vándamāno dadhāti ' pitấ vaso yádi táj joṣáyāse 'The praising father establishes many names (for you), O good one, (in order to see) whether you will enjoy it'; AB 5.34.4 tasmād yadi yajña rkta ārtih syāt ... 'Therefore, if in a sacrifice with a Rigvedic (verse) an accident would happen ...'. Subjunctive and optative are likewise common in subordinate clauses with yád 'if; so that' (the latter meaning mostly in the early language), yátha 'as, like; in order/so that'; céd 'if' is common with the optative in Vedic prose; etc.

\section{Acknowledgement}

This article was finalized thanks to a grant from the ERC (grant agreement 313416, EVALISA project) to Jóhanna Barðdal and thanks to a Marie Skłodowska-Curie grant from the European Commission (Grant Agreement number 702895, TRIA project). I am very grateful to Jared Klein and Alexander Lubotsky for valuable remarks and comments on earlier drafts.

\section{Abbreviations}

$\begin{array}{llll}\text { AB } & \text { Aitareya-Brāhmaṇa } & \text { AVP } & \text { AV, Paippalāda recension } \\ \bar{A} p S ́ S & \text { Āpastamba-Śrauta-Sūtra } & \text { Br. } & \text { Brāhmaṇas } \\ \text { AV(ŚS) } & \text { Atharvaveda (Śaunakīya } & \text { GB } & \text { Gopatha-Brāhmaṇa } \\ & \text { recension) } & \text { KauśS } & \text { Kauśika-Sūtra }\end{array}$




$\begin{array}{llll}\text { KB } & \text { Kaușītaki-Brāhmaṇa } & \text { ŚrSū. } & \text { Śrauta-Sūtras } \\ \text { KS } & \text { Kāṭhaka(-Saṃhitā) } & \text { Sū. } & \text { Sūtras } \\ \text { JB } & \text { Jaiminīya-Brāhmaṇa } & \text { TB } & \text { Taittirīya-Brāhmaṇa } \\ \text { MānGS } & \text { Mānava-Grhya-Sūtra } & \text { TS } & \text { Taittirīya-Saṃhitā } \\ \text { MS } & \text { Maitrāyan̄ī Saṃhitā } & \text { VādhS } & \text { Vādhūla-Sūtra } \\ \text { Rām. } & \text { Rāmāyaṇa } & \text { VaikhŚS } & \text { Vaikhānasa-Śrauta-Sūtra } \\ \text { RV } & \text { Rogveda } & \text { VaitS } & \text { Vaitāna-Sūtra } \\ \text { RVKh. } & \text { Rogveda-Khilāni } & \text { VS } & \text { Vājasaneyi-Saṃhitā } \\ \text { ŚB(M) } & \text { Satapatha-Brāhmaṇa } & \text { YV } & \text { Yajurveda(-Saṃhitā) }\end{array}$

\section{References}

The most comprehensive surveys of Old Indo-Aryan syntax can be found in Delbrück 1888, 18931897; Speijer [Speyer] 1886, 1896; Elizarenkova 1982, 380ff.

Andersen, Paul Kent

1986 The genitive agent in Rigvedic passive constructions. In: Franciszek Sławski (ed.), Collectanea linguistica in honorem Adami Heinz. Wrocław: Zakład Narodowy im. Ossolińskich, 9-13.

Bubenik, Vit

1987 Passivized causatives in Sanskrit and Prākrits. Linguistics 25: 687-704.

Casaretto, Antje

2011a Syntax und Wortarten der Lokalpartikeln des Rgveda. IX: ánu. Münchener Studien zur Sprachwissenschaft 65: 7-64.

Casaretto, Antje

2011b Syntax und Wortarten der Lokalpartikeln des Rgveda. XII: ví. Historische Sprachforschung 124: 134-177.

Dahl, Eystein

2009 Some semantic and pragmatic aspects of object alternation in Early Vedic. In: Jóhanna Barðdal and Shobhana L. Chelliah (eds.), The role of semantic, pragmatic, and discourse factors in the development of case. (Studies in Language Companion Series 108). Amsterdam: Benjamins, 23-55.

Delbrück, Berthold

1888 Altindische Syntax. Halle an der Saale: Verlag der Buchhandlung des Waisenhauses.

Delbrück, Berthold

1893-1897 Vergleichende Syntax der indogermanischen Sprachen. 3 Theile. Strassburg: Trübner.

Deshpande, Madhav M.

1991 Ditransitive passive in Pāṇini. Indo-Iranian Journal 34: 19-35.

Dunkel, George

1982 Autour de á Rg-Védique (A lexical study). Indo-Iranian Journal 24: 89-102.

Dunkel, George

2014 Lexikon der indogermanischen Partikeln und Pronominalstämme. Heidelberg: Winter.

Elizarenkova, Tat'jana Jakovlevna

1982 Grammatika vedijskogo jazyka [A grammar of the Vedic language]. Moscow: Nauka.

Gaedicke, Carl

1880 Der Accusativ im Veda. Breslau: Koebner.

Gonda, Jan

1951 Remarks on the Sanskrit passive. (Orientalia Rheno-Traiectina 4). Leiden: Brill. 
Gonda, Jan

1957a The character of the Sanskrit accusative. In: Diego Catalán (ed.), Miscelánea homenaje a André Martinet: Estructuralismo e historia. Tomo I. La Laguna: Biblioteca Filológica Universidad de la Laguna, 47-65. [= Gonda 1975, 44-62.]

Gonda, Jan

1957b A note on the function of the accusative as described in the handbooks. In: Sarvepalli Radhakrishnan, Vasudev Vishnu Mirashi, Ramchandra Narayan Dandekar, Sushil Kumar De, Venkatarama Raghavan, and Anant Sadashiv Altekar (eds.), Felicitation volume presented to Professor Sripad Krishna Belvalkar. Banaras: Motilal Banarasidass, 72 80. [= Gonda 1975, 63-71.]

Gonda, Jan

1975 Selected Studies. Vol. I. Indo-European linguistics. Leiden: Brill.

Gonda, Jan

1979 The medium in the Rgveda. (Orientalia Rheno-Traiectina 24). Leiden: Brill.

Gotō, Toshifumi

1996 [1987] Die "I. Präsensklasse" im Vedischen: Untersuchung der vollstufigen thematischen Wurzelpräsentia. 2., überarb. und ergänzte Aufl. Vienna: Verlag der Österreichi-

Gotō, Toshifumi schen Akademie der Wissenschaften.

1997 Überlegungen zum urindogermanischen «Stativ». In: Emilio Crespo and José Luis García Ramón (eds.), Berthold Delbrück y la sintaxis indoeuropea hoy. Actas del Coloquio de la Indogermanische Gesellschaft. Wiesbaden: Reichert, 165-192.

Gotō, Toshifumi

2002 Funktionen des Akkusativs und Rektionsarten des Verbums - anhand des Altindoarischen. In: Heinrich Hettrich (ed.), Indogermanische Syntax - Fragen und Perspektiven. Wiesbaden: Reichert, 21-42.

Gotō, Toshifumi

2013 Old Indo-Aryan morphology and its Indo-Iranian background. In co-operation with Jared S. Klein and Velizar Sadovski. (Sitzungsberichte der philosophisch-historischen Klasse 849; Veröffentlichungen zur Iranistik 60). Vienna: Verlag der Österreichischen Akademie der Wissenschaften.

Grassmann, Hermann

1873 Wörterbuch zum Rig-Veda. Leipzig: Brockhaus.

Haudry, Jean

1977 L'emploi des cas en védique. Introduction à l'étude des cas en indo-européen. Lyon: l'Hermès.

Hettrich, Heinrich

1988 Untersuchungen zur Hypotaxe im Vedischen. Berlin: De Gruyter.

Hettrich, Heinrich

1990 Der Agens in passivischen Sätzen altindogermanischen Sprachen. (Nachrichten der Akademie der Wissenschaften in Göttingen. I. Philol.-hist. Klasse; Jg. 1990, 2). Göttingen: Vandenhoeck \& Ruprecht.

Hettrich, Heinrich

1991 Syntax und Wortarten der Lokalpartikeln des Rogveda. I: ádhi. Münchener Studien zur Sprachwissenschaft 52: 27-76.

Hettrich, Heinrich

1993[-1994] Syntax und Wortarten der Lokalpartikeln des Rgveda. II: antár. Münchener Studien zur Sprachwissenschaft 54: 147-176.

Hettrich, Heinrich

1994 Semantische und syntaktische Betrachtungen zum doppelten Akkusativ. In: George E. Dunkel, Gisela Meyer, Salvatore Scarlata, and Christian Seidl (eds.), Früh-, Mittel-, Spätindogermanisch. Wiesbaden: Reichert, 111-134. 
Hettrich, Heinrich

1995 Zur funktionalen Variationsbreite altindogermanischer Kasus: Der Ablativ im Rgveda. In: Heinrich Hettrich, Wolfgang Hock, Peter-Arnold Mumm, and Norbert Oettinger (eds.), Verba et Structurae. Festschrift für Klaus Strunk zum 65. Geburtstag. Innsbruck: Institut für Sprachwissenschaft der Universität, 53-72.

Hettrich, Heinrich

2002 Syntax und Wortarten der Lokalpartikeln des Rogveda. III: pári. In: Matthias Fritz and Susanne Zeilfelder (eds.), Novalis Indogermanica. Festschrift für Günter Neumann zum 80. Geburtstag. Graz: Leykam, 215-242.

Hettrich, Heinrich

2007 Materialien zu einer Kasussyntax des Rgveda. Würzburg: Institut für Altertumswissenschaften der Universität. (Internet Publication: http://www.vergl-sprachwissenschaft. phill.uni-wuerzburg.de/materialien/Materialien.pdf)

Hettrich, Heinrich

2010 tanū- als Reflexivpronomen im Rogveda? In: Jeanette C. Fincke (ed.), Festschrift für Gernot Wilhelm anläßlich seines 65. Geburtstages am 28. Januar 2010. Dresden: ISLET, 175-183.

Hock, Hans Henrich

1981 Sanskrit causative syntax: a diachronic study. Studies in the Linguistic Sciences 11: 933.

Hock, Hans Henrich

1982 The Sanskrit passive: synchronic behavior and diachronic development. South Asian Review 6: 127-137.

Hock, Hans Henrich

1985 Sanskrit double-object constructions: Will the real object please stand up? Praci-Bhasha-Vijnan: Journal of Indian Linguistics 12: 50-70.

Hock, Hans Henrich

1985-1986 Voice, mood, and the gerundive (krtya) in Sanskrit. In: Indologica Taurinensia 13 (Proceedings of the $6^{\text {th }}$ World Sanskrit Conference): 81-102.

Hock, Hans Henrich

1990 Oblique subjects in Sanskrit? In: Manindra K. Verma and Karuvannur Puthanveettil Mohanan (eds.), Experiencer subjects in South Asian languages. Stanford: Center for the Study of Language and Information, 119-139.

Hock, Hans Henrich

1991 Causees, passive agents, or instruments? Instrumental NPs with causatives in early and later Vedic Prose. In: Hans Henrich Hock (ed.), Studies in Sanskrit syntax: A volume in honor of the centennial of Speijer's Sanskrit Syntax (1886-1986). Delhi: Motilal Banarsidass, 71-93.

Hock, Hans Henrich

1997 Nexus and 'extraclausality' in Vedic, or 'sa-figé' all over again: A historical (re)examination. In: Hans Henrich Hock (ed.), Historical, Indo-European, and lexicographical studies: A festschrift for Ladislav Zgusta on the occasion of his $70^{\text {th }}$ birthday. Berlin: Mouton de Gruyter, 49-78.

Hock, Hans Henrich

2006 Reflexivization in the Rig-Veda (and beyond). In: Heinrich Hettrich and Bertil Tikkanen (eds.), Themes and tasks in Old and Middle Indo-Aryan Linguistics. Papers of the $12^{\text {th }}$ World Sanskrit Conference. Vol. 5. Delhi: Motilal Banarsidass, 19-44.

Hoffmann, Karl

1967 Der Injunktiv im Veda. Eine synchronische Funktionsuntersuchung. Heidelberg: Winter. Holland, Gary B.

1986 Relativization and word order in Old Irish and Vedic Sanskrit. Journal of Indo-European Studies 24: 323-331. 
Jamison, Stephanie W.

1979a The case of the agent in Indo-European. Die Sprache 25: 129-143.

Jamison, Stephanie W.

1979b Remarks on the expression of agency with the passive in Vedic and Indo-European. Zeitschrift für vergleichende Sprachforschung 93: 196-219.

Jamison, Stephanie W.

1982 Case disharmony in Rgvedic similes. Indo-Iranian Journal 24: 252-271.

Jamison, Stephanie W.

1983 Function and form in the -áya-formations of the Rig Veda and Atharva Veda. (Zeitschrift für vergleichende Sprachforschung auf dem Gebiete der indogermanischen Sprachen, Ergänzungsheft 31). Göttingen: Vandenhoeck \& Ruprecht.

Jamison, Stephanie W.

1992 Vedic "sá figé": An inherited sentence connective? Historische Sprachforschung 105: 213-239.

Joachim, Ulrike

1978 Mehrfachpräsentien im Rgveda. Frankfurt am Main: Peter Lang.

Keydana, Götz

1997 Absolute Konstruktionen in altindogermanischen Sprachen. (Historische Sprachforschung, Ergänzungsheft 40). Göttingen: Vandenhoeck \& Ruprecht.

Keydana, Götz

2013 Infinitive im Rgveda: Formen, Funktion, Diachronie. (Brill's Studies in Indo-European Languages \& Linguistics 9). Leiden: Brill.

Klein, Jared S.

1978 The particle u in the Rigveda: A synchronic and diachronic study. Göttingen: Vandenhoeck und Ruprecht.

Klein, Jared S.

1985 Toward a discourse grammar of the Rigveda. Vol. I: Coordinate conjunction. Pt. 1: Introduction, ca, utá. Pt. 2: u; áthā, átho, ádha, ād; vā; ápi. Heidelberg: Winter.

Klein, Jared S.

1996 'Sá-figé' and Indo-European Deixis. Historische Sprachforschung 109: 21-39.

Klein, Jared S.

1998 Rigvedic syáltyá-. In: Jay Jasanoff, H. Craig Melchert, and Lisi Oliver (eds.), Mír curad. Studies in honor of Calvert Watkins. Innsbruck: Institut für Sprachwissenschaft der Universität, 361-372.

Klein, Jared S.

2004-2005 Relative pronoun sequences in the Rigveda: A syntactic, rhetorical-poetic, and discourse-level study. Bulletin d'Études Indiennes 22-23: 495-536.

Knobl, Werner

forthcoming Das Demonstrativpronomen ETÁD im Rgveda. In: Lucien van Beek et al. (eds.), Indo-Iranian and its Indo-European origins. Festschrift for Alexander Lubotsky. Ann Arbor: Beech Stave Press.

Krisch, Thomas

1999 Zur Reziprozität in altindogermanischen Sprachen. In: Heiner Eichner and Hans Christian Luschützky (eds.) unter redaktioneller Mitwirkung von Velizar Sadovski, Compositiones Indogermanicae: in memoriam Jochem Schindler. Prague: Enigma, 273-297.

Krisch, Thomas

2006 RIVELEX: Rigveda-Lexikon Bd. 1. (Grazer vergleichende Arbeiten 20). Graz: Leykam.

Krisch, Thomas

2012 RIVELEX: Rigveda-Lexikon. Bd. 2. (Grazer vergleichende Arbeiten 26). Graz: Leykam.

Kulikov, Leonid

1999a May he prosper in offspring and wealth: A few jubilee remarks on the typology of labile verbs and Sanskrit púsyati 'prospers; makes prosper'. In: Ekaterina V. Rakhilina and 
Yakov G. Testelets (eds.), Tipologija i teorija jazyka: Ot opisanija $k$ ob”jasneniju. K 60-letiju A. E. Kibrika. [Typology and linguistic theory: From description to explanation. For the $60^{\text {th }}$ birthday of Aleksandr E. Kibrik]. Moscow: Jazyki russkoj kultury, 224244.

Kulikov, Leonid

1999b Split causativity: Remarks on correlations between transitivity, aspect, and tense. In: Werner Abraham and Leonid Kulikov (eds.), Tense-aspect, transitivity and causativity. Essays in honour of Vladimir Nedjalkov. (Studies in Language Companion Series 50). Amsterdam: Benjamins, 21-42.

Kulikov, Leonid

2000 Vedic causative nasal presents and their thematicization: a functional approach. In: John Charles Smith and Delia Bentley (eds.), Historical linguistics 1995. Vol. 1: General issues and non-Germanic languages. Amsterdam: Benjamins, 191-209.

Kulikov, Leonid

2003 The labile syntactic type in a diachronic perspective: The case of Vedic. SKY Journal of Linguistics 16: 93-112.

Kulikov, Leonid

2006 Passive and middle in Indo-European: Reconstructing the early Vedic passive paradigm. In: Werner Abraham and Larisa Leisiö (eds.), Passivization and typology: Form and function. (Typological Studies in Language 68). Amsterdam: Benjamins, 62-81.

Kulikov, Leonid

2007a Reciprocal constructions in Vedic. In: Vladimir P. Nedjalkov (ed.), Reciprocal construcKulikov, Leonid tions. (Typological Studies in Language 71). Vol. 2. Amsterdam: Benjamins, 709-738.

2007b The reflexive pronouns in Vedic: A diachronic and typological perspective. Lingua 117: $1412-1433$.

Kulikov, Leonid

2008 The Vedic causative saṃkhyāpáyati/samkśápáyati reconsidered. In: Leonid Kulikov and Maxim Rusanov (eds.), Indologica. T. Ya. Elizarenkova Memorial Volume (Orientalia et Classica 20). Book 1. Moscow: Izd-vo RGGU, 245-261.

Kulikov, Leonid

2011 Passive to anticausative through impersonalization: The case of Vedic and Indo-European. In: Anna Siewierska and Andrej Malchukov (eds.), Impersonal constructions. A cross-linguistic perspective. (Studies in Language Companion Series 124). Amsterdam: Benjamins, 229-254.

Kulikov, Leonid

2012a The Vedic -ya-presents: Passives and intransitivity in Old Indo-Aryan. (Leiden Studies in Indo-European 19). Amsterdam: Rodopi.

Kulikov, Leonid

$2012 \mathrm{~b}$ Vedic preverbs as markers of valency-changing derivations: Transitivity and objecthood in Indo-European (Evidence from Old Indo-Aryan). Studies in Language 36: 721-746.

Kulikov, Leonid

2012c Voice and valency derivations in Old Indo-Aryan in a diachronic typological perspective: the degrammaticalization of the middle and other trends in the Vedic verbal system. In: Lucio Melazzo (ed.), Usare il presente per spiegare il passato. Teorie linguistiche contemporanee e lingue storiche. Atti del XXXIII Convegno della Società Italiana di Glottologia. Palermo, 16-18 ottobre 2008 (Biblioteca della Società Italiana di Glottologia 35). Rome: Il Calamo, 161-191.

Kulikov, Leonid

2013 Constraints on the causative derivation in early Vedic: Evidence for a diachronic typology of transitivity. Poznań Studies in Contemporary Linguistics 49: 79-101. 
Kulikov, Leonid

2014a Grammaticalization of reciprocal pronouns in Indo-Aryan: Evidence from Sanskrit and Indo-European for a diachronic typology of reciprocal constructions. Journal of South Asian Languages and Linguistics 1.2: 117-156.

Kulikov, Leonid

2014b The decline of labile syntax in Old Indo-Aryan: A diachronic typological perspective. Linguistics 52.4 (special issue: Typology of labile verbs: Focus on diachrony, guest-eds. Leonid Kulikov and Nikolaos Lavidas): 1139-165.

Kümmel, Martin

1996 Stativ und Passivaorist im Indoiranischen. (Historische Sprachforschung, Ergänzungsheft 39). Göttingen: Vandenhoeck \& Ruprecht.

Kümmel, Martin

2000 Das Perfekt im Indoiranischen. Eine Untersuchung der Form und Funktion einer ererbten Kategorie des Verbums und ihrer Weiterentwicklung in den altindoiranischen Sprachen. Wiesbaden: Reichert.

Kupfer, Katharina

2002 Die Demonstrativpronomina im Rigveda. (Europäische Hochschulschriften. Reihe XXI. Linguistik 244). Frankfurt am Main: Peter Lang.

Lowe, John J.

2015 Participles in Rigvedic Sanskrit: The syntax and semantics of adjectival verb forms (Oxford Studies in Diachronic and Historical Linguistics 17). Oxford: Oxford University Press.

Macdonell, Arthur Anthony

1910 Vedic grammar. (Grundriss der Indo-Arischen Philologie und Altertumskunde, Bd. I, Heft 4). Strassburg: Trübner.

Macdonell, Arthur Anthony

1916 A Vedic Grammar for Students. Oxford: Clarendon Press.

Narten, Johanna

1968 Zum ,proterodynamischen“ Wurzelpräsens. In: Jan C. Heesterman, Godard H. Schokker, and Vadasery Iyemperumal Subramoniam (eds.), Pratidānam: Indian, Iranian, and IndoEuropean Studies Presented to Franciscus Bernardus Jacobus Kuiper on his Sixtieth Birthday. The Hague: Mouton, 9-19.

Oertel, Hanns

1926 The Syntax of Cases in the Narrative and Descriptive Prose of the Brāhmanas. I. The Disjunct Use of Cases. Heidelberg: Winter.

Ostler, Nicholas

1979 A theory of case and verb diathesis applied to Classical Sanskrit. Unpublished MIT Ph.D. dissertation.

Pinault, Georges-Jean

1985a Emploi et analyse des adverbes comparatifs sanskrits en -vat. In: Bernfried Schlerath (ed.), Grammatische Kategorien. Funktion und Geschichte. Akten der VII. Fachtagung der Indogermanischen Gesellschaft. Wiesbaden: Reichert, 340-369.

Pinault, Georges-Jean

1985b Négation et comparaison en védique. Bulletin de la Société de Linguistique 80: 103144.

Pinault, Georges-Jean

1995-1996 Distribution des particules comparatives dans la R̊k-Samitā. Bulletin d'Études Indiennes 13-14: 307-367.

Pinault, Georges-Jean

2001 Védique tanú- et la notion de personne en indo-iranien. Bulletin de la Société de Linguistique 96: 181-206. 
Renou, Louis

1933 La séparation du préverbe et du verbe en védique. Bulletin de la Société de Linguistique 34: 49-96.

Renou, Louis

1952 Grammaire de la langue védique. Lyon: IAC.

Ruppel, Antonia

2013 Absolute Constructions in Early Indo-European. (Cambridge Classical Studies). Cambridge: Cambridge University Press.

Schäufele, Steven

1991 Free word-order syntax: The challenge from Vedic Sanskrit to contemporary formal syntactic theory. Unpublished University of Illinois at Urbana-Champaign Ph.D. dissertation.

Schneider, Carolin

2009 Syntax und Wortarten der Lokalpartikeln des R.gveda V: ní. Historische Sprachforschung 122: $118-169$.

Sen, Sukumar

1927 The use of the cases in Vedic prose. Annals of the Bhandarkar Oriental Research Institute 8: 347-378; 9: 33-48, 91-170; 10: 45-76, 219-234. [Reprinted in: Sukumar Sen. Syntactic studies of Indo-Aryan languages. Tokyo: Institute for the study of languages and cultures of Asia and Africa, 1995].

Speijer [Speyer], Jacob S.

1886 Sanskrit syntax. (Grundriss der Indo-Arischen Philologie und Altertumskunde, Bd. I, Heft 6). Leiden: Brill.

Speijer [Speyer], Jacob S.

1896 Vedische und Sanskrit-Syntax. Strassburg: Trübner.

Thieme, Paul

1929 Das Plusquamperfektum im Veda. (Zeitschrift für vergleichende Sprachforschung auf dem Gebiete der indogermanischen Sprachen, Ergänzungsheft 7). Göttingen: Vandenhoeck \& Ruprecht.

Tichy, Eva

1995 Die nomina agentis auf-tar-im Vedischen. Heidelberg: Winter.

Tichy, Eva

2006 Der Konjunktiv und seine Nachbarkategorien: Studien zum indogermanischen Verbum, ausgehend von der älteren vedischen Prosa. Bremen: Hempen.

Tikkanen, Bertil

1987 The Sanskrit gerund: A synchronic, diachronic and typological analysis. (Studia Orientalia 62). Helsinki: Finnish Oriental Society.

Verbeke, Saartje, Leonid Kulikov, and Klaas Willems

2015 Oblique case-marking in Indo-Aryan experiencer constructions: historical roots and synchronic variation. Lingua 163: 23-39.

Vine, Brent

1997 On the expression of reflexive possession in the Rig-Veda: RV svá-. In: Eric Pirart (ed.), Viti, Carlotta

Syntaxe des langues indo-iraniennes anciennes. Barcelona: Editorial Ausa, 203-214.

2007 The verb-initial word order in the early poetry of Vedic and Homeric Greek. In: Karlene Jones-Bley, Martin E. Huld, Angela Della Volpe, and Miriam Robbins Dexter (eds.), Proceedings of the $19^{\text {th }}$ Annual UCLA Indo-European Conference, Los Angeles, November 3-4 2007. Washington, DC: Institute for the Study of Man, 89-111.

Viti, Carlotta

2008 The phylogenesis of hypotaxis in Vedic. Diachronica 25: 386-409. 
Viti, Carlotta

2009 A quantitative analysis of the OSV word order in Vedic. In: Elisabeth Rieken and Paul Widmer (eds.), Pragmatische Kategorien. Form, Funktion und Diachronie (Akten der Arbeitstagung der Indogermanischen Gesellschaft vom 24. bis 26. September 2007 in Marburg). Wiesbaden: Reichert, 307-322.

Viti, Carlotta

2010 The information structure of OVS in Vedic. In: Gisella Ferraresi and Rosemarie Lühr (eds.), Diachronic Studies on Information Structure: Language Acquisition and Change. Berlin: De Gruyter, 37-62.

Wackernagel, Jacob and Albert Debrunner

1896-1930 Altindische Grammatik. 3 vols. (I 1896, ${ }^{2} 1957$; II,1 1905, ${ }^{2} 1957$; II,2 1954; III 1930; Register 1964). Göttingen: Vandenhoeck \& Ruprecht.

Wecker, Otto

1906 Der gebrauch der kasus in der älteren Upanișad-literatur verglichen mit der kasuslehre der indischen grammatiker. Bezzenbergers Beiträge 30: 1-61, 177-207.

Wenzel, Heinrich

1879 Ueber den Instrumentalis im Rigveda. Tübingen: Verlag der H. Laupp'schen Buchhandlung.

Whitney, William Dwight

1889 Sanskrit grammar. $2^{\text {nd }}$ edn. Cambridge, Mass.: Harvard University Press.

Zehnder, Thomas

2011a Zur Funktion der Infinitive im Veda. In: Thomas Krisch and Thomas Lindner (eds.), Indogermanistik und Linguistik im Dialog. Akten der XIII. Fachtagung der Indogermanischen Gesellschaft vom 21. bis 27. September 2008 in Salzburg. Wiesbaden: Reichert, 622-631.

Zehnder, Thomas

2011b Das periphrastische Kausativ im Vedischen. (Münchner Forschungen zur historischen Sprachwissenschaft 12). Bremen: Hempen.

Zehnder, Thomas

2016 Review of: Keydana 2013. Journal of South Asian Languages and Linguistics 3.1: 133139

Leonid Kulikov, Ghent (Belgium) and Pavia (Italy)

\section{The lexicon of Indic}

1. Introduction

2. Inherited Vocabulary

3. Loan words
4. Specific vocabulary

5. Word formation

6. References

\section{Introduction}

The Indo-Aryan (IA) branch of Indo-European is roughly to be differentiated into Old (OIA), Middle (MIA), and New Indo-Aryan (NIA). The native term Sanskrit denotes the OIA language in contrast to the native term Prākrit, which corresponds to MIA. 